\title{
Characterizing storm response and recovery using the beach change envelope: Fire Island, New York
}

\author{
Owen T. Brenner a,*, Erika E. Lentz ${ }^{\text {b }}$, Cheryl J. Hapke ${ }^{\text {a }}$, Rachel E. Henderson ${ }^{\text {c }}$, Kat E. Wilson ${ }^{\text {c }}$, Timothy R. Nelson ${ }^{\text {a }}$ \\ a U.S. Geological Survey, St. Petersburg Coastal and Marine Science Center, 600 4th St South, St Petersburg, FL 33701, United States \\ ${ }^{b}$ U.S. Geological Survey, Woods Hole Coastal and Marine Science Center, 384 Woods Hole Rd, Woods Hole, MA 02543, United States \\ c Cherokee Nation Technologies contracted to U.S. Geological Survey, St. Petersburg Coastal and Marine Science Center, 600 4th St South, St Petersburg, FL 33701, United States
}

\section{A R T I C L E I N F O}

Article history:

Received 3 February 2017

Received in revised form 1 August 2017

Accepted 2 August 2017

Available online 3 August 2017

\section{Keywords:}

Barrier Island

Coastal geomorphology

Storm response

Beach recovery

\begin{abstract}
A B S T R A C T
Hurricane Sandy at Fire Island, New York presented unique challenges in the quantification of storm impacts using traditional metrics of coastal change, wherein measured changes (shoreline, dune crest, and volume change) did not fully reflect the substantial changes in sediment redistribution following the storm. We used a time series of beach profile data at Fire Island, New York to define a new contour-based morphologic change metric, the Beach Change Envelope (BCE). The BCE quantifies changes to the upper portion of the beach likely to sustain measurable impacts from storm waves and capture a variety of storm and post-storm beach states. We evaluated the ability of the BCE to characterize cycles of beach change by relating it to a conceptual beach recovery regime, and demonstrated that BCE width and BCE height from the profile time series correlate well with established stages of recovery. We also investigated additional applications of this metric to capture impacts from storms and human modification by applying it to several post-storm historical datasets in which impacts varied considerably; Nor'Ida (2009), Hurricane Irene (2011), Hurricane Sandy (2012), and a 2009 community replenishment. In each case, the BCE captured distinctive upper beach morphologic change characteristic of these different beach building and erosional events. Analysis of the beach state at multiple profile locations showed spatial trends in recovery consistent with recent morphologic island evolution, which other studies have linked with sediment availability and the geologic framework. Ultimately we demonstrate a new way of more effectively characterizing beach response and recovery cycles to evaluate change along sandy coasts.
\end{abstract}

Published by Elsevier B.V.

\section{Introduction}

Storms are considerable drivers of rapid and often dramatic changes to coastal areas, particularly dunes and beaches along sandy coastlines. The resulting impacts from these events require a range of human and natural resource considerations, from threats to buildings and infrastructure to changes in habitat availability (Schlacher et al., 2007; Weinstein et al., 2007; FitzGerald et al., 2008; Gutierrez et al., 2009; Moser et al., 2014; Passeri et al., 2015). Often in the days and weeks following an event there is significant pressure to restore beaches and dunes through replenishment projects, wherein the potential for natural recovery is either overlooked (Lazarus, 2014), considered spatially and temporally insufficient, and/or poorly understood and as a consequence not factored into decision-making. Therefore measurements and characterizations of coastal change that can account for both storm impacts and recovery are essential for actionable and targeted coastal management.

A number of established metrics are traditionally used to determine morphology change along sandy coastlines (barrier islands, mainland

\footnotetext{
* Corresponding author.

E-mail address: obrenner@usgs.gov (O.T. Brenner).
}

beaches, etc.), and generally fall into two categories. One category measures a single morphologic proxy (e.g. shoreline position (Morton et al., 1995; Thieler and Young, 1991; Farris and List, 2007; Houser et al., 2008; Hapke et al., 2010, 2016; Bramato et al., 2012; Phillips et al., 2017) or dune height (Houser et al., 2008, 2015; Stockdon et al., 2009; Wernette et al., 2016)); whereas the other simplifies spatial information along a cross-shore profile to an averaged value (e.g. beach volume and slope) (Morton et al., 1994; Stone et al., 2004; Stockdon et al., 2007; Houser and Hamilton, 2009; Mathew et al., 2010; Scott et al., 2016). Changes in these metrics can be used to better resolve timescales (e.g. hourly, monthly, and decadal) of morphodynamic processes driving coastal response (e.g. dune/beach erosion and scarping) and recovery (e.g. beach building, dune accretion and profile sand flux), and typically vary alongshore due to sediment availability and the underlying geology of the area (e.g. Scott et al., 2016; Castelle et al., 2017).

A considerable body of published literature has documented storm impacts (e.g. Zeigler et al., 1959; Lee et al., 1998; Houser et al., 2008; Castelle et al., 2015; Suanez et al., 2015) to sandy beaches (Wright and Short, 1984; Sexton and Hayes, 1991; Morton, 2002; Priestas and Fagherazzi, 2010) and dunes (Saunders and Davidson-Arnott, 1990, Hesp, 2002; Psuty et al., 2005; McLean and Shen, 2006; Houser, 2012; Plant and Stockdon, 2012; Lentz et al., 2013; Houser et al., 2015; 
Weymer et al., 2013; Wilson et al., 2015). These studies assess change using a variety of beach metrics including island volume, shoreline and dune position, and profile topography from consecutive elevation surveys (i.e. LiDAR and cross-shore elevation profiles) to evaluate alongshore variability, and compare multiple events. This information has been used to link observations with what is known about localized sediment supply and geology of a system (e.g. Aagaard et al., 2004; Houser et al., 2008; Lentz et al., 2013; Schwab et al., 2013; Warner et al., 2014; Hapke et al., 2016), providing better understanding of the signature these controls may exert on an area.

Despite the variety of metrics available to characterize coastal change, the post-storm recovery of dunes and beaches is less wellstudied than storm-driven change, but has received more attention recently (Weymer et al., 2013; Houser et al., 2015; Scott et al., 2016; Castelle et al., 2017; Phillips et al., 2017). In contrast to the timescales of event-driven changes which are fixed (i.e. the duration of the event, in days), and therefore straightforward to evaluate, recovery intervals themselves are temporally varying (days, weeks, months, seasons, years) depending on the degree of change (Wang et al., 2006; Mathew et al., 2010; Bramato et al., 2012) and cross-shore location (beach vs. dune), making the definition of the term itself limited to the interval of the study (i.e. recovery with respect to what reference point). Furthermore, where storm-driven change is typically determined by the hydrodynamics of the event including waves, tides, and storm surge (Lee et al., 1998; Stockdon et al., 2007; Sallenger, 2000; Suanez et al., 2015), recovery can be affected by both hydrodynamic conditions (e.g. Scott et al., 2016) and aeolian sediment transport (e.g. Anthony et al., 2006; Houser, 2009), which themselves require different instrumentation and understanding to measure and track. Coupled with the spatially (and temporally) varying levels of recovery that occur from the shoreline to the dunes (Phillips et al., 2017; Castelle et al., 2017), the measurement, evaluation, or characterization of recovery is challenging, particularly in a way that is meaningful across sites or locations (Morton et al., 1994; Hesp, 2002; Houser and Hamilton, 2009; Mathew et al., 2010; Houser et al., 2015; Scott et al., 2016).

Reflecting the complexity in studying recovery, only a handful of investigations have directly approached beach recovery and used observed changes in beach morphology evolution to describe physical processes and specifics of progressing (or regressing) from one state or condition to another (Wright and Short, 1984; Morton et al., 1994; Boothroyd, 1999; Hesp, 2002). Hesp (2002) focused primarily on the foredune, and used conceptualizations of foredune erosion, establishment, and recovery processes to develop an evolutionary model of theoretical beach erosion and recovery pathways. Wright and Short (1984) extracted specialized metrics from beach profile datasets to explore interactions between the wave climate and beach morphology at six identified beach states (i.e. ranging from highly dissipative to highly reflective), and the wave conditions and morphologic change required to transition from one beach state to another. Morton et al. (1994) assessed beach profile volume and the general presence and position of morphologic features (i.e. shoreline, berm crest, and vegetation line), to identify four theoretical beach stages, each with prescribed feature and volumetric conditions, used to asses net post-storm recovery at various profile locations. Boothroyd (1999) presents a similar sequence of recovery states within a conceptual model of storm induced impacts and recovery. This quantitative model is derived from decades of profile data and uses the emergence of key beach, dune and island features (e.g. berm, backshore dune, barrier core) to define specific recovery stages, and provides a general temporal scale (e.g. days, weeks, months, years, decades, etc.) associated with each sequential phase. Collectively, the recovery pathways outlined in these studies (Wright and Short, 1984; Morton et al., 1994; Boothroyd, 1999; Hesp, 2002) identify four to six distinct beach states associated with progressively greater degrees of recovery, from a relatively featureless poststorm profile that widens in the days following the storm event as eroded sand moves back onshore and welds to the swash zone and lower shoreface, followed by a series of phases documenting the accumulation of sand at progressively higher and more landward positions along the profile from the foreshore, to the upper beach (a.k.a. backbeach or beach berm), and eventually to the foredune and dune (e.g. Houser, 2009).

The impact of Hurricane Sandy at Fire Island, New York helped to identify a need for a new metric that could be used to monitor the spatial and temporal variability of both storm response and subsequent recovery alongshore. Storm-induced changes varied considerably alongshore ranging from moderate erosion and scarping, to dune leveling through overwash and island inundation. As previously described by Hapke et al. (2013, 2015), traditional one dimensional shoreline change calculations were insufficient to demonstrate the complex impacts at Fire Island that shifted material from the upper beach to the lower beach, causing a positive signal for shoreline change while the majority of the profile was depleted (Fig. 1a). Similarly, measuring positional changes to the dune crest or even the dune toe, was not possible in many alongshore locations because dunes themselves were no longer present and therefore devoid of standard reference points for comparison (Hapke et al., 2013). More generally, volume change, while possible to quantify, did not isolate the region of the profile undergoing morphologic change, and therefore did not define where sediment had been distributed along the profile (Hapke et al., 2015) (Fig. 1b). For example, profile volumes can be similar for two very different profile configurations as shown in Fig. 1b: one that includes substantial shoreface welding bars on an eroded post-storm profile, and another a mature well-developed berm (e.g. upper berm or dune region) and a steeply sloping shoreface resulting from prolonged fair weather conditions. Although shoreline change may reflect this difference in morphology, the cross-shore shoreline position is largely dictated by the topography of the foreshore (e.g. shoreface slope, presence and width of beach berm and/or swash bar) and is not necessarily correlated to the remainder of the profile (dune and upper beach) or overall profile volume (Fig. 1). Emergency restoration efforts immediately following the storm to improve access and protect property could have been made more targeted and potentially effective with an understanding of what sections of beach had been hardest hit, and also, which were likely to recover most rapidly.

A U.S. Geological Survey beach profile monitoring program (http:// coastal.er.usgs.gov/fire-island/research/sandy/beach-profiles.html and Henderson et al., 2017), initiated a few days before Hurricane Sandy made landfall, provided the opportunity to measure and monitor both storm response and recovery with a low-cost and temporally robust dataset that would be collected over the subsequent weeks, months and years following the storm. Using these data, we generally observed that the beach located above the MHW shoreline and below the dune toe: a) was susceptible to nearly all storms (but not eliminated), b) was not drastically influenced by smaller meteorological or tidal conditions, c) could often recuperate following storms fairly quickly and effectively (weeks to months), and d) was typically a precursor to dune recovery (e.g. Morton et al., 1994). Furthermore, due to its location, the state of this upper portion of the beach governs many natural resource management actions and access issues at Fire Island; in addition to offering important habitat to threatened species (e.g. migratory birds), the upper beach is also where many recreational activities occur, is often used as a continuous shore parallel vehicle access where driving is permitted, and hence is often the target for beach replenishment projects.

In this paper, we develop an upper beach metric, the Beach Change Envelope, and test its ability to: 1) quantify observed upper beach storm response and recovery; 2 ) associate quantified values with the identified stages of post-storm beach recovery; and 3) track recovery progress over a variety of timescales to better describe the beach recovery process within a conceptual regime. We hypothesize that careful examination of the upper beach will allow us to better quantify and characterize beach response over various timescales, and more importantly, 


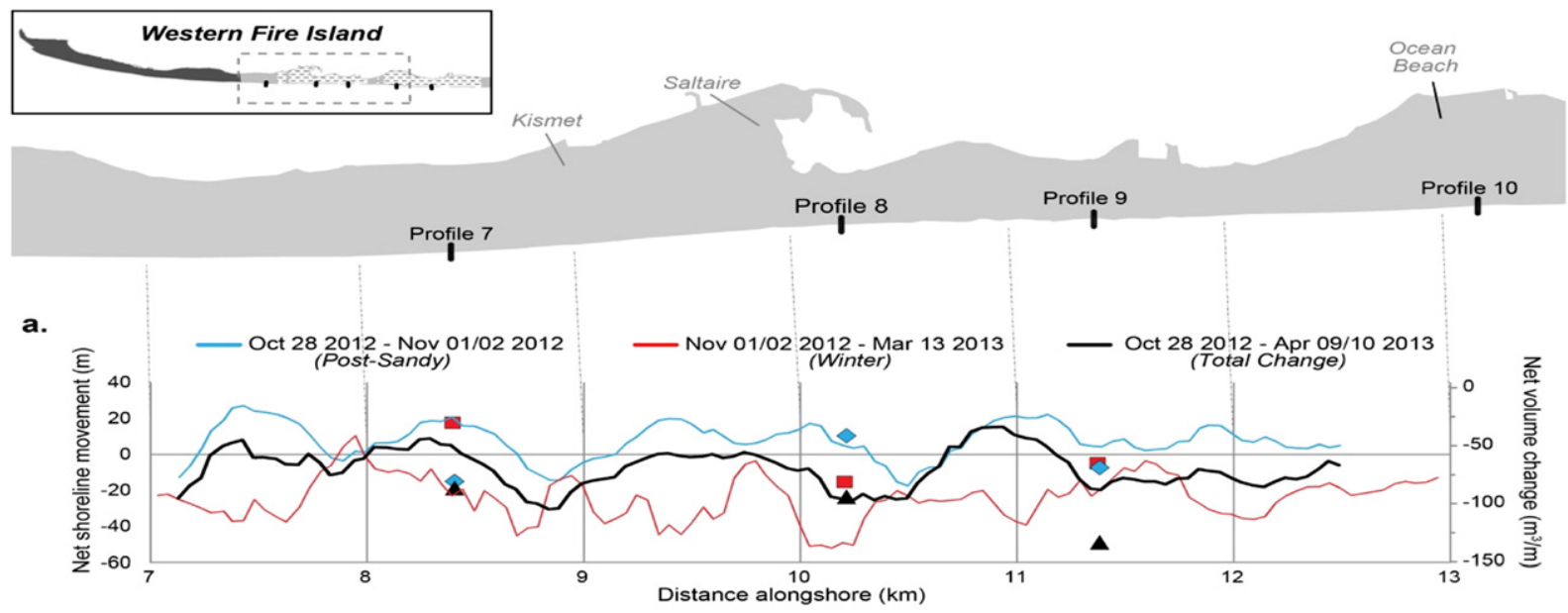

b.

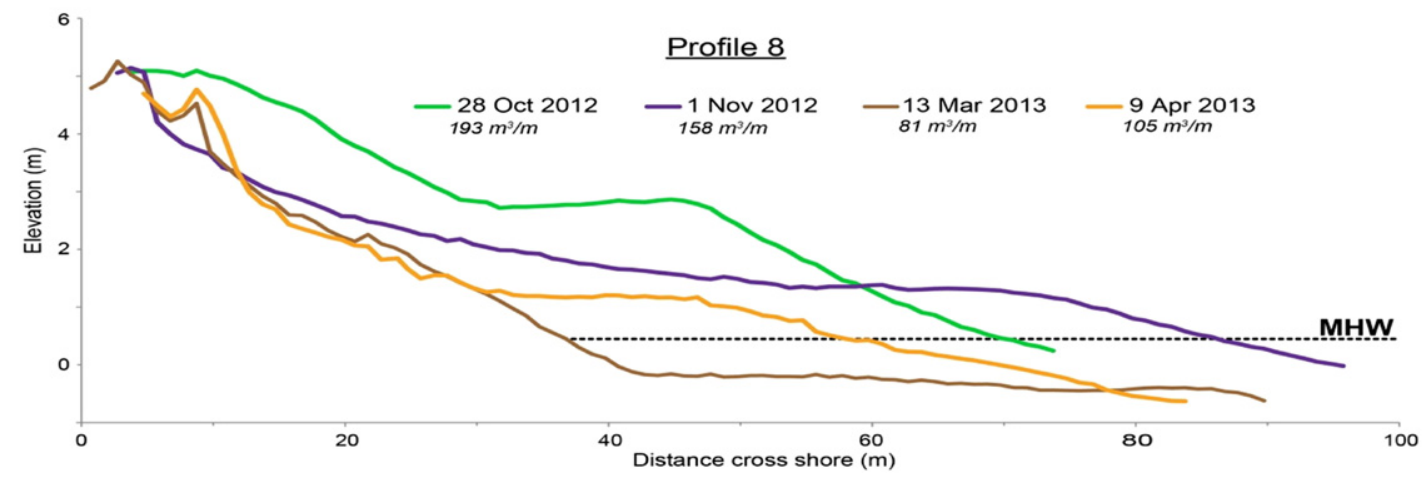

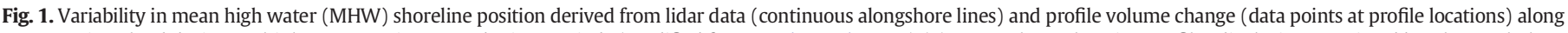

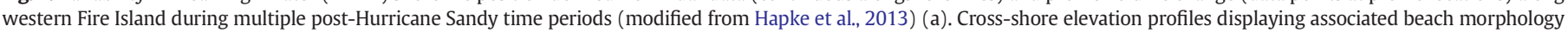

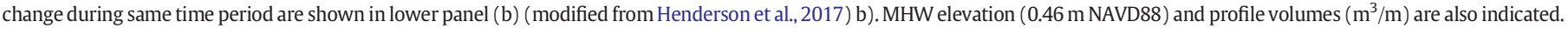

sustained post-storm recovery that can be used to better evaluate alongshore vulnerability, and support development of models to predict storm response and beach recovery. The extensive profile database and coastal setting makes Fire Island an ideal pilot site to develop and test an approach we anticipate will be transferrable to sandy beach environments worldwide.

\section{Regional setting}

Centrally located along the southern shore of Long Island, Fire Island is a $50 \mathrm{~km}$-long barrier island system extending from Fire Island Inlet northeast to Moriches Inlet and separating Great South Bay from the Atlantic Ocean (Fig. 2a). The majority of Fire Island is less than $1 \mathrm{~km}$ wide, relatively low-lying with dune elevations rarely exceeding $10 \mathrm{~m}$, and features a highly variable subaerial morphology (Leatherman, 1985). The barrier island is a microtidal, wave-dominated system with a mean tidal range of $1.3 \mathrm{~m}$ (Davis and Hayes, 1984; Leatherman, 1985). Mean significant wave height of $1.3 \mathrm{~m}$ and a dominant mean period of $7.3 \mathrm{~s}$ are measured approximately $44 \mathrm{~km}$ off western Fire Island (Wilson et al., 2015; NOAA, NDBC \#44025). Prevailing winds are out of the southwest, however predominant wave and storm approach from the southeast (NOAA, 2010) drives a westerly net alongshore sediment transport direction (Leatherman, 1985).

There are three morphologically distinct regions of the island (Fig. 2b). Western Fire Island exhibits rapid westward spit progradation and relatively wide beaches backed by moderately sized dunes $(4.5 \mathrm{~m}$ average) due to large sediment inputs via cross-shore and alongshore transport - as evidenced by consecutive recurved dune ridges and alongshore distance between Fire Island Inlet and extending four miles west of the Fire Island Lighthouse, which was originally constructed in 1826 to mark the eastern flank of the inlet (Leatherman,
1985, Leatherman and Allen, 1985; Hapke et al., 2010, 2011, 2016; Lentz et al., 2013, Schwab et al., 2013). The central portion, approximately from Sailors Haven to Watch Hill, is thought to be the oldest part of the island and has many well established $10+\mathrm{m}$-high dune ridges and has historically been the most stable of the three regions showing minimal landward migration of the past 1000 years (Leatherman, 1985; Psuty and Silveira, 2009). The eastern portion of the island, east of Watch Hill, is relatively low-lying, consists of series of historic inlet and breach features (i.e. relic flood shoals, expansive backbarrier marshes, washover channels, and recurved dunes). Without an offshore sediment source, and potentially exposed to a harsher nearshore wave conditions due to featureless and deeper nearshore bathymetry, the east has shown steady landward transgression via breaching and overwash during the past 200 years (Leatherman, 1985; Leatherman and Allen, 1985; Lentz et al., 2013).

Fire Island is divided into three public parklands and 17 private communities (Fig. 2b), however 42 of the $50 \mathrm{~km}$ of the island are within the Fire Island National Seashore (FIS) and all the frontal beaches and dunes along the island, except those in Robert Moses State Park, are managed by the National Park Service (NPS). Portions of the island directly within the national park, including the federally designated Fire Island Otis Pike High Dune Wilderness Area (Wilderness Area), experience minimal and primarily indirect anthropogenic beach modification. By contrast, the 17 moderately developed communities have utilized large-scale dune and berm building nourishment projects with the two most recent and substantial one being a community-led nourishment project in 2009 and the Fire Island Stabilization Project as part of the U.S. Army Corps of Engineers designed Fire Island Inlet to Montauk Point Project (FIMP). The 2009 nourishment project emplaced 1.4 million cubic meters $\left(\mathrm{m}^{3}\right)$ of sand along beaches fronting 11 communities, while the FIMP project, encompassing all portions of the island except the national 


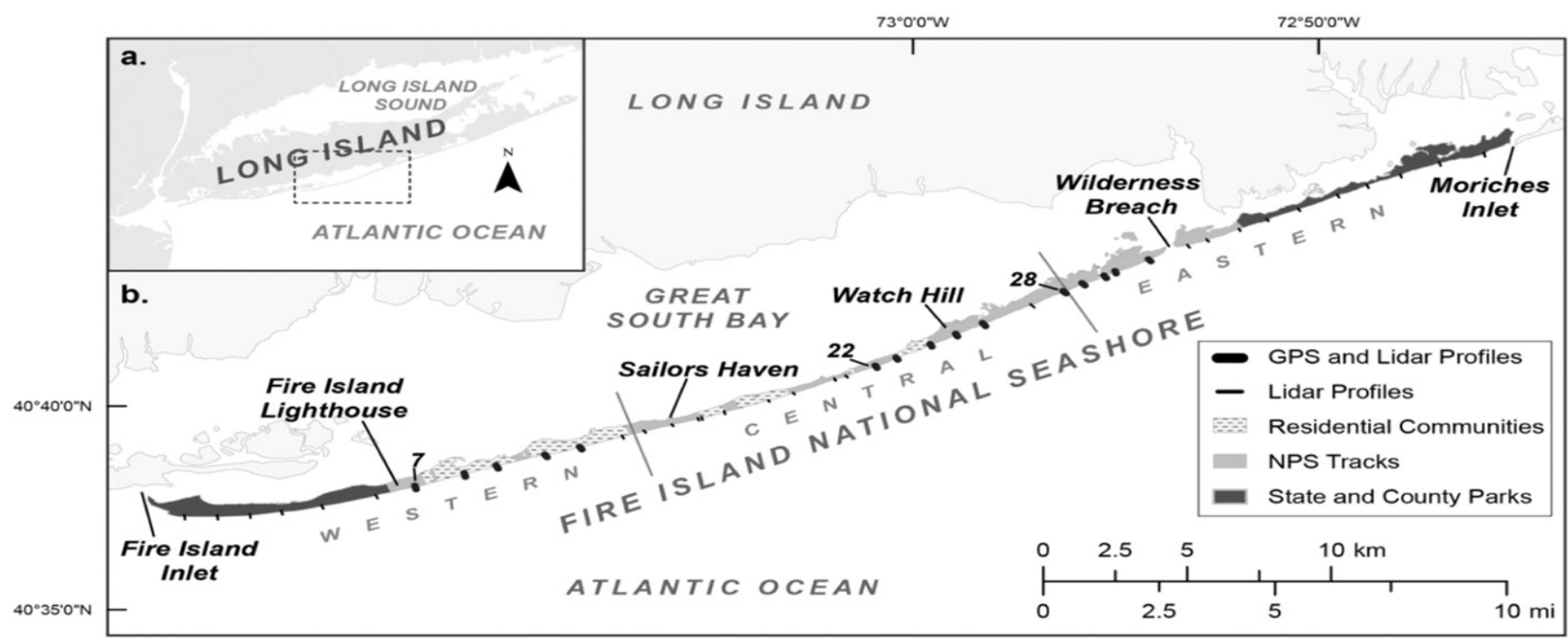

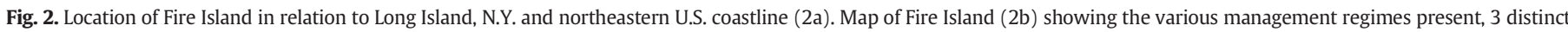
geologic regions (western, central and eastern) and beach profile locations.

parklands, is expected to deposit 5.3 million $\mathrm{m}^{3}$ of sand primarily within a nearly continuous alongshore dune $3.05-4.57 \mathrm{~m}$ wide by $7.62 \mathrm{~m}$ high (Fire Island Beach Renourishment Project: Post-construction Report, 2009; FIMI, 2014). Additionally, smaller localized modifications efforts (e.g. beach scraping, dune building, dune armoring with sand bags) are used to mitigate ongoing beach erosion (Lentz and Hapke, 2011; Kratzmann and Hapke, 2012; Lentz et al., 2013).

\subsection{Storm history and anthropogenic modifications}

Oriented southwest to northeast, the island is exposed to extratropical storms and hurricanes approaching from the south, typically occurring mid-summer to late-fall, and nor'easter storms, extratropical cyclonic storms along the East Coast of North America named for their dominant northeasterly wind direction and primarily forming in the late fall and winter. Due largely to variable along-island morphology, storm impacts can range from beach and dune erosion to inundation and breaching (Leatherman 1985; Lentz and Hapke, 2011; Kratzmann and Hapke, 2012; Wilson et al., 2015; Hapke et al., 2015). Average storm surge elevation values are $0.6 \mathrm{~m}$ (MSL) for annual storms and $1.2 \mathrm{~m}$ for the 10-year interval storm (Schwab et al., 2000), however, recorded high water marks (which include surge, tide, and wave run-up) on western Fire Island after Hurricane Sandy were as high as $2.9 \mathrm{~m}$ (McCallum et al., 2013).

Fire Island has an extensive storm history (Lentz et al., 2013), with five of the more recent storms relatively well documented with preand post-storm surveys that were included in our analysis (Tables 1,2).
All five storms within the beach profile record (Table 1) were included in the determination of the wave impact zone (Section 3.2); the unique and fairly distinctive impacts of the latter three storms (Nor'Ida, Hurricanes Irene and Sandy) are described in Table 1 and were further used in developing and testing the metric introduced in this paper.

\section{Methods}

\subsection{Elevation datasets}

\subsubsection{Beach profiles (GPS)}

To document the impacts of Hurricane Sandy and post-storm beach recovery and evolution, cross-shore beach profiles were collected in the days immediately preceding the storm (October 2012) and have been collected at weekly, then monthly, then quarterly intervals through 2016 (Table 2) (Hapke et al., 2013; Henderson et al., 2015, 2017). The locations and positioning of the profiles (http://coastal.er.usgs.gov/ fireisland/research/sandy/beach-profiles.html) were largely determined by pre-Sandy data survey coverage (Hapke et al., 2013) and corresponded with earlier USGS Fire Island beach morphology studies (Lentz and Hapke, 2011). Originally the GPS beach profile surveys included ten profile locations in western and central Fire Island which include a survey collected two days before Sandy, and in January 2014 five eastern profiles were added and consistently surveyed. The 15 cross-shore profiles encompass both nourished and engineered beaches within developed communities and undeveloped tracks of Fire Island National Seashore (FIS). Profiles are surveyed from dune crest to low-

Table 1

Name, date and general impact for storms within the recent historic storm record at Fire Island, NY and used in this study

\begin{tabular}{|c|c|c|}
\hline Name & Date & Impact \\
\hline Halloween Storm & $10 / 2005$ & The extended duration ( 5 days) and peak wave heights $6 \mathrm{~m}$ leading to widespread erosion along the island (Lentz and Hapke, 2011). \\
\hline $\begin{array}{l}\text { Patriot's Day } \\
\text { Nor'easter }\end{array}$ & 4/2007 & $\begin{array}{l}\text { With } 5.5 \mathrm{~m} \text { peak wave heights this nor'easter caused substantial beach and dune erosion, particularly within central Fire Island communities } \\
\text { (Lentz and Hapke, 2011). }\end{array}$ \\
\hline Nor'Ida & $11 / 2009$ & $\begin{array}{l}\text { Peak wave heights greater than } 6 \mathrm{~m} \text { and dominant periods over } 8 \mathrm{~s} \text { were recorded at the offshore buoy (NDBC: } 44,025) \text { and ultimately led to } \\
\text { substantial beach erosion and dune scarping along most beaches, many of which had recently been renourished (Lentz et al., 2013). }\end{array}$ \\
\hline Hurricane Irene & $8 / 2011$ & $\begin{array}{l}\text { Largely an accretional event; steady onshore southwest winds, modest } 4-5 \mathrm{~m} \text { offshore wave heights, unusually long duration of long period } \\
\text { swell throughout the storm and elevated water levels appeared to move material from the lower portion of the shoreface to the near-dune and } \\
\text { upper beach regions (National Park Service News Release, 2011; Hapke et al., 2012). }\end{array}$ \\
\hline Hurricane Sandy & $10 / 2012$ & $\begin{array}{l}\text { Historic levels of coastal inundation and extensive beach erosion as offshore wave heights approached } 10 \mathrm{~m} \text { with } 13 \mathrm{~s} \text { wave periods. } \\
\text { Morphologic impacts ranged from frontal dune erosion and scarping to extensive dune overwashing, flattening of the primary dune, and/or } \\
\text { complete island breaching (Hapke et al., 2013). }\end{array}$ \\
\hline
\end{tabular}


Table 2

GPS survey dates contained within the post- Hurricane Sandy profile dataset. Post-Sandy GPS profile data are limited to $10-15$ profile locations along Fire Island (Fig. 2b).

\begin{tabular}{ll}
\hline Year & Survey dates $^{\mathrm{a}}$ \\
\hline 2012 & $10 / 28,11 / 2,11 / 4,12 / 1,12 / 12$ \\
2013 & $1 / 10,2 / 13,3 / 13,4 / 9,6 / 24,9 / 20,12 / 3$ \\
2014 & $1 / 29,6 / 11,9 / 9,10 / 7$ \\
2015 & $1 / 21,3 / 19,5 / 16,9 / 28$ \\
\hline
\end{tabular}

a Data Source: U.S. Geological Survey Data Series 931; Hurricane Sandy beach response and recovery at Fire Island, New York: Shoreline and beach profile data, October 2012 to October 2014.

tide swash zone using a wheel mounted Differential Global Positioning System (DGPS) antenna (i.e. Ashtech Z-Xtreme Survey System with reported instrument horizontal and vertical accuracies values of 1 and $2 \mathrm{~cm}$, respectively). As reported in Henderson et al. (2015), average values of uncertainty for the profile data are $\pm 0.04 \mathrm{~m}$ and $\pm 0.05 \mathrm{~m}$ for the horizontal and vertical dimensions respectively. Although surveys are ongoing, we limit the post-Sandy morphology change assessment in this paper to the nearly three year post-storm period which includes 19 surveys from November 1, 2012 to September 28, 2015.

\subsubsection{Historical beach profiles (LiDAR)}

In addition to the GPS surveyed profiles, we extracted additional pre- and post-storm data (i.e. from GPS surveys (Lentz and Hapke, 2011) and lidar datasets (as in Lentz et al., 2013)) at 42 profile locations, for five storm events between 2005 and 2012, including Hurricane Sandy (Table 3). Variability in LiDAR point cloud data has been found to result in an uncertainty value of $\pm 0.15 \mathrm{~m}$ for features extracted from interpolated topographic surfaces (Sallenger et al., 2003).

\subsection{Deriving the beach change envelope}

We used our spatially and temporally dense morphologic dataset to define the portion of the beach that was historically impacted only during storm events and recovered on near-term timescales (months, years). Our approach focused on morphology, as opposed hydrodynamic conditions, after experiments with the available and more spatially and temporally sparse hydrodynamic metrics revealed alongshore variations in wave run-up were ultimately determined by differences in morphology (beach slope). Pre- and post-storm beach profiles for five storms were used to isolate the storm wave impact zone (Fig. 3a, Table 3). Following a methodology introduced in Hapke et al. (2015), the landward-most location within the storm wave impact zone $\left(E_{i}\right)$, was used to define the vertical limit (elevation, NAVD88) of wave incursion $\left(E_{z}\right)$ along the profile during a storm (Fig. 3a). The $E_{z}$ was determined at all 42 profile locations for each of the five storms, and an average (over time and space) $\mathrm{E}_{\mathrm{z}}$ value of $2.3 \mathrm{~m}$ was calculated. The Beach Change Envelope (BCE) was determined as one standard deviation $( \pm 0.6 \mathrm{~m})$ from the mean $\mathrm{E}_{\mathrm{z}}$ value of $2.3 \mathrm{~m}$. This resulted in upper $\left(\mathrm{Z}_{\mathrm{u}}\right)$ and lower $\left(\mathrm{Z}_{\mathrm{l}}\right)$ BCE contours of $2.9 \mathrm{~m}$ and $1.7 \mathrm{~m}$, respectively
(Fig. 3b). Furthermore, the assigned values of $\mathrm{E}_{\mathrm{z}}, \mathrm{Z}_{\mathrm{u}}$ and $\mathrm{Z}_{\mathrm{l}}$, and potentially the approach used to calculate these elevations, are likely unique to each dataset and may vary within a single study area given substantial alongshore disparity often found in coastal systems (e.g. sediment characteristics, wave climate, beach morphology). The established contours limit the BCE to the portion of the beach most commonly impacted during storms, and with a near-term (months, years) recovery timeline different from the more rapidly changing shorelines (days, weeks) and more slowly responding dunes (years to decades) (Fig. 3c) (Hapke et al., 2015). Ultimately, the BCE is the portion of the profile where we expected the timing and degree of subsequent impact and recovery would be most easily observed and interpreted on seasonal to interannual management timescales. Along meso- and macrotidal coasts, where both extreme tidal events and storms drive beach morphology change, the BCE could be applied by adjusting $Z_{u}$ and $Z_{1}$ as needed.

A systematic visual inspection of the position of the $Z_{u}$ and $Z_{1}$ elevation contour was conducted for nearly $70 \%$ of the 26 pre- and poststorm beach profiles to ensure that the BCE bounded the proper portion of the profile necessary document change along the upper beach area. This confirmed that the calculated $Z_{1}$ elevation of $1.7 \mathrm{~m}$ was sufficiently located above mean higher high water (MHHW) to avoid including impacts due to smaller wave events corresponding with high spring tides. We also verified that $Z_{\mathrm{u}}$ at $2.9 \mathrm{~m}$ was landward of the berm and seaward of the foredune ramp and dune toe to ensure that the upper beach, and not the dune, was within the BCE (e.g. Fig. 3c). In addition, this assessment also helped to identify resolve occasional ambiguity in $Z_{\mathrm{u}}$ and $\mathrm{Z}_{\mathrm{l}}$ positions due to the large variability in the profile morphologies, and to further constrain, and explicitly define, $Z_{\mathrm{u}}$ and $Z_{1}$ positions as needed for coded metric extraction from entire profile dataset. For example, post- Hurricane Sandy, some locations had a repeatedly absent $Z_{\mathrm{u}}$ due to extensive overwash and breaching during the storm (e.g. Fire Island Lighthouse vicinity) therefore at these locations only a $Z_{1}$ is recorded. In other cases, the $Z_{u}$ or $Z_{1}$ contour intersected the profile multiple times due to ridges and swales on the beach, therefore profiles were also inspected to confirm that the seaward-most occurrence of the $Z_{u}$ and $Z_{1}$ was recorded. Presumably, the application of the BCE method along other coastal systems, or during appreciably different morphologic change events, would require a similar process of visual inspection to ensure the selection of optimal $Z_{u}$ and $Z_{1}$ positions.

$Z_{u}$ and $Z_{1}$ were extracted from the entire profile (historical and postSandy) database to examine changes to the BCE through time (Table 3). Positional data were used to calculate the distance between the contours (BCE width), BCE slope (slope of the profile between the contours), BCE volume, and landward migration rate. Extracted values were output as tables at specific profile locations by survey date, and as time-series plots showing co-evolution of beach profile morphology and BCE position through time (Fig. 4).

\subsection{Linking $B C E$ to storm response and recovery}

Plotting beach profiles and BCE configuration time series (Fig. 4), allowed links between morphologic beach change and changes in BCE

Table 3

Pre- and post-storm surveys used in formulating BCE boundaries.

\begin{tabular}{|c|c|c|c|}
\hline Survey date & Storm & Data type & Data link \\
\hline $4 / 25 / 2005$ & Pre-Halloween & LiDAR & http://pubs.usgs.gov/of/2006/1384/ \\
\hline $11 / 1 / 2005$ & Post-Halloween & LiDAR & https://coast.noaa.gov/htdata/lidar1_z/geoid12a/data/33/ \\
\hline $3 / 20 / 2007$ & Pre-Patriot's Day & GPS & Lentz and Hapke, 2011; http://dx.doi.org/10.1016/j.geomorph.2010.10.032 \\
\hline $4 / 29 / 2007$ & Post-Patriot's Day \& Pre-Nourishment & LiDAR & https://pubs.er.usgs.gov/publication/70134308 \\
\hline $7 / 9 / 2009$ & Post-Nourishment \& Pre-Nor'Ida & LiDAR & http://pubs.usgs.gov/ds/565/ \\
\hline $11 / 27 / 2009$ & Post-Nor'Ida & LiDAR & https://coast.noaa.gov/htdata/lidar1_z/geoid12a/data/1170/ \\
\hline $8 / 23 / 2010$ & Pre-Irene & LiDAR & https://coast.noaa.gov/htdata/lidar1_z/geoid12a/data/1179 \\
\hline $8 / 31 / 2011$ & Post-Irene & LiDAR & https://doi.org/10.5066/F7VT1Q7V \\
\hline $5 / 7 / 2012$ & Pre-Sandy & LiDAR & http://coastal.er.usgs.gov/data-release/doi-F7513WBW/ \\
\hline $11 / 05 / 2012$ & Post-Sandy & LiDAR & https://coast.noaa.gov/htdata/lidar1_z/geoid12a/data/2488 \\
\hline
\end{tabular}


a.

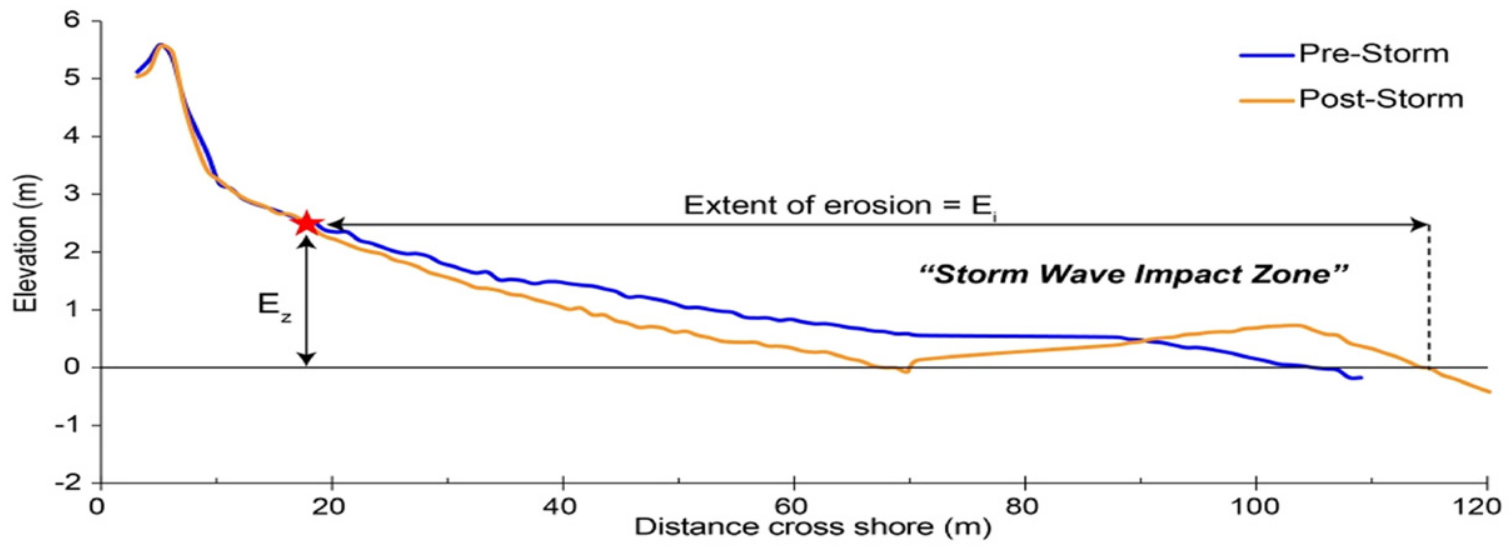

b.

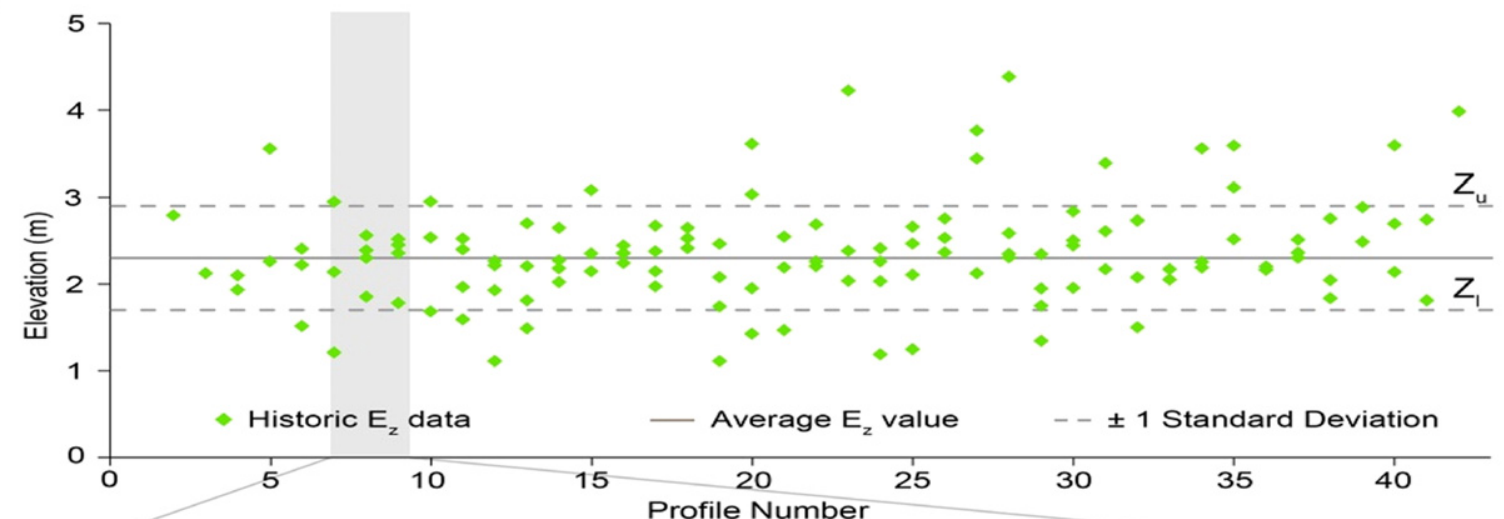

c.

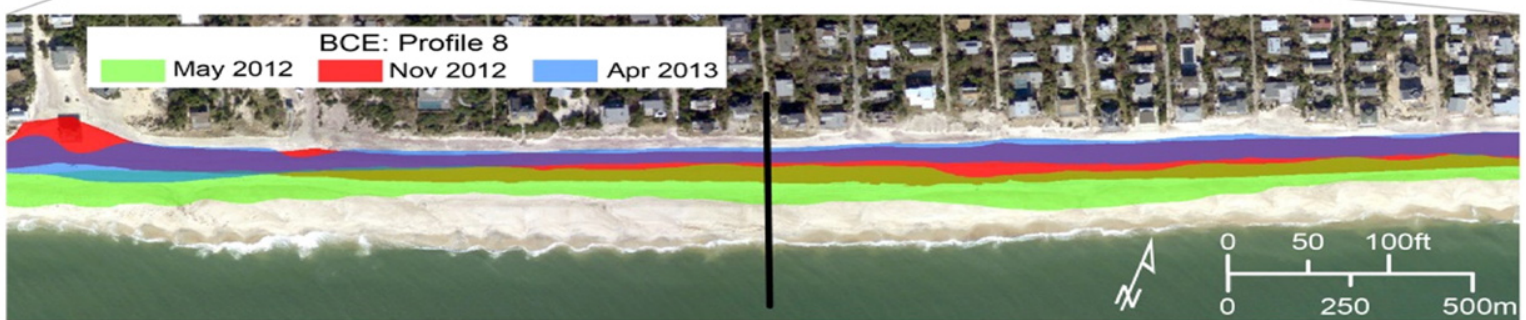

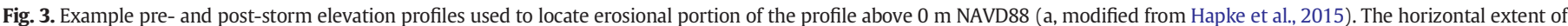

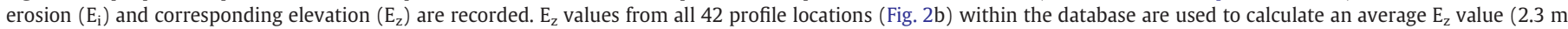

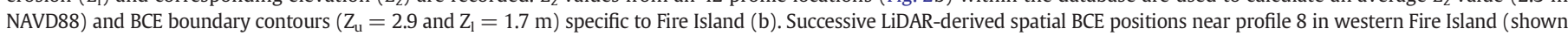
by shaded vertical bar in b) prior to and throughout the winter following, Hurricane Sandy (c).

to be more thoroughly examined. In this analysis, the quantitative $\mathrm{BCE}$ metrics, average height $\left(\mathrm{BCE}_{\mathrm{H}}\right)$ and width $\left(\mathrm{BCE}_{\mathrm{W}}\right)$, introduced in Hapke et al. (2015) were revised to develop a technique of using both metrics to assess beach state. $\mathrm{BCE}_{\mathrm{W}}$ is the cross-shore distance between $Z_{\mathrm{u}}$ and $Z_{1}$ and defines the horizontal extent of the BCE (Fig. 5). $B C E_{H}$ was calculated as the mean profile elevation value within the $B C E$ from $Z_{u}$ to $Z_{1}$ at $1 \mathrm{~m}$ increments. To quantify profile curvature, $\mathrm{BCE}_{\mathrm{H}}$ is normalized by $2.3 \mathrm{~m}$, which by definition is the median $\mathrm{BCE}$ elevation and theoretically represents a planar BCE surface with no curvature (Fig. 5) (e.g. Hapke et al., 2013). BCE ${ }_{H}$ values greater than 1 indicate an elevated upper beach and berm (Fig. 5; dotted profile) while $\mathrm{BCE}_{\mathrm{H}}$ values less than 1 reflect a more eroded or scoured upper beach zone (Fig. 5; dashed profile). This evaluation of the $\mathrm{BCE}$ curvature with $\mathrm{BCE}_{\mathrm{H}}$ helped identify the geomorphic physical processes (i.e. wave impact vs. aeolian transport) that was most actively affecting this portion of the beach, and therefore was useful in assessing beach state and recovery (Morton et al., 1994: Priestas and Fagherazzi, 2010).

Once calculated, we evaluated the application of these BCE metrics to quantitatively capture upper beach changes in line with beach recovery stages (Wright and Short, 1984; Morton et al., 1994). We focused on the co-evolution of $\mathrm{BCE}_{\mathrm{W}}$ and $\mathrm{BCE}_{\mathrm{H}}$ to better resolve the timescales and physical processes related to beach recovery states. $\mathrm{BCE}_{\mathrm{W}}$ is used to assess storm erosion, and subsequent periods of recovery through ongoing accretion. $\mathrm{BCE}_{\mathrm{H}}$ values are used to distinguish where sand is being stored along the profile; high values indicate sand is in the upper BCE zone while lower values reflect sand being stored lower (or elsewhere) on the foreshore (e.g. Fig. 5).

We used historical data to test this methodological and quantitative approach for relating specific BCE configurations and changes with degrees of storm impact and the individual stages of post-storm recovery. Qualitative assessments of expected BCE behavior were made for each of the primary stages of beach response as detailed by Morton et al. (1994) (Table 4). We then assessed the expected influence of natural beach recovery on $\mathrm{BCE}$ configuration (relative $\mathrm{BCE}_{\mathrm{H}}$ and $\mathrm{BCE}_{\mathrm{W}}$ values) by examining geomorphic responses in the recovery period following Sandy to identify: 1 ) potential BCE behaviors indicating recovery was underway, and 2) morphologic behaviors that signified the individual stages of the recovery process. Finally, we evaluated BCE characterization of upper beach change in response to Nor'Ida, Hurricane Irene, Hurricane Sandy, and a 2009 community-based nourishment event by examining changes to $\mathrm{BCE}_{\mathrm{H}}$ and $\mathrm{BCE}_{\mathrm{W}}$ as well as positional changes 


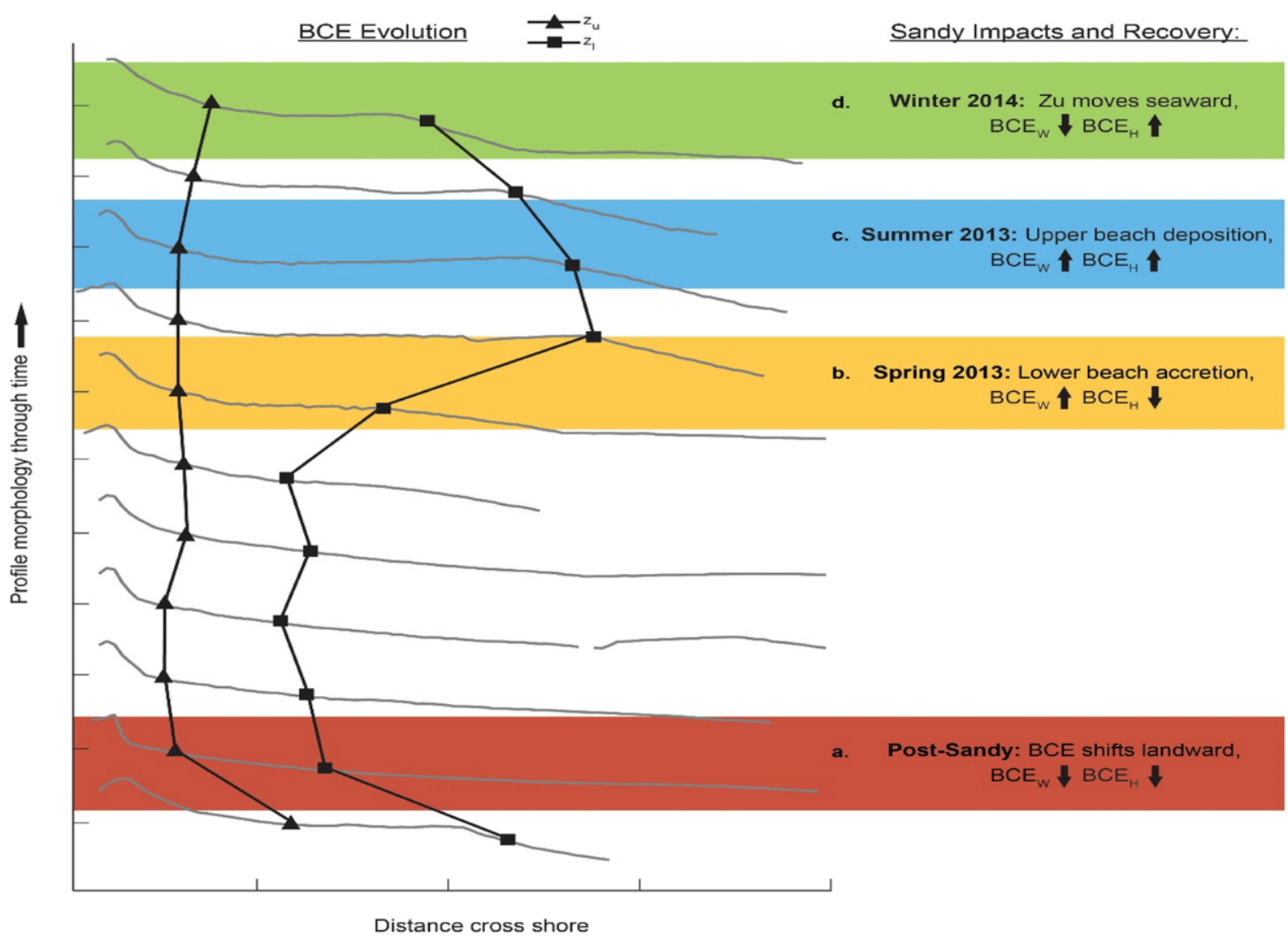

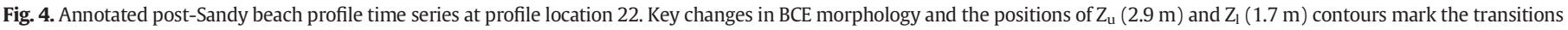
between various beach recovery states and are within colored bars.

to $Z_{\mathrm{u}}$ and $Z_{\mathrm{l}}$ for the 15 eastern, central and western profile locations (Table 4).

All data used in the generation of results and analyses can be accessed by following weblinks provided in the text, tables, and references given herein. Readers are referred initially to U.S. Geological Survey Data Release Henderson et al. (2017).

\section{Results}

\subsection{Evaluating BCE response to Hurricane Sandy}

Post-Sandy evolution of beach profile and BCE during key periods of beach recovery (e.g. spring-summer of 2013 and 2014) demonstrates that a similar progression of physical changes at many profile locations and measurable levels of recovery have occurred. As shown in Fig. 4, the BCE shifted landward and was both narrow and low immediately following Hurricane Sandy in late October 2012 (Fig. 4a). Following a series of consecutive nor'easters the profiles began to rebound through forebeach accretion and widening. This phase of recovery is shown during the spring and early summer of 2013 when wide, low beach profiles caused rapid $\mathrm{BCE}_{\mathrm{W}}$ increases (Fig. 4b). Despite seasonal oscillations in beach morphology, continued beach accretion produced a more elevated upper beach as evident by late summer and early fall (Fig. 4c). During fall of $2013 \mathrm{BCE}_{\mathrm{W}}$ remained wide as sand continued to move onshore, and $\mathrm{BCE}_{\mathrm{H}}$ began to increase due to upper beach aggradation. Eventually, the beach further recovered from the storm and dune recovery prograded into the upper beach area, resulting in $\mathrm{BCE}_{\mathrm{W}}$ narrowing and continued high values of $\mathrm{BCE}_{\mathrm{H}}$. This stage had yet to be achieved

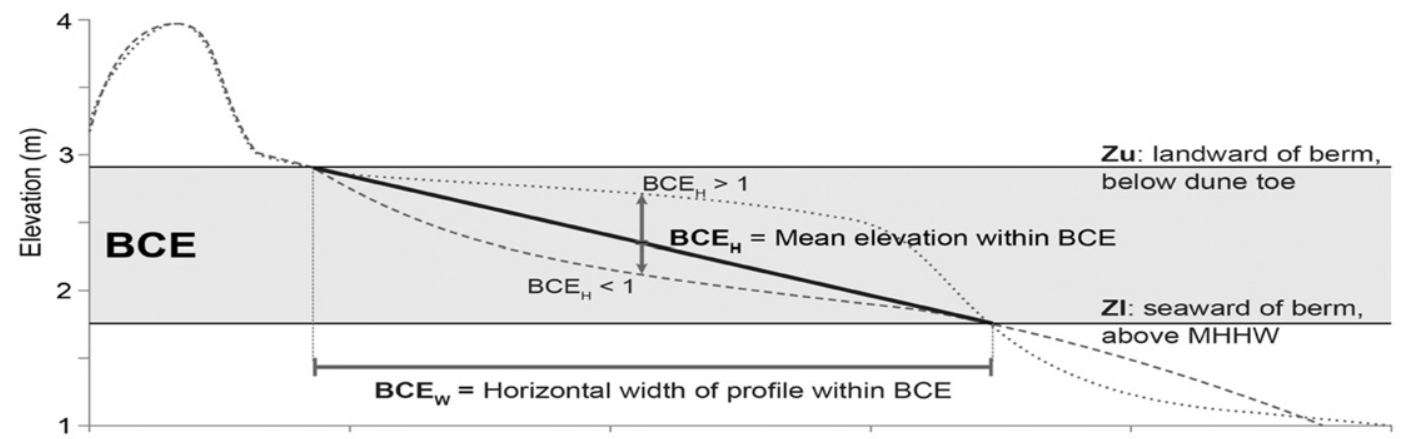

Distance cross shore $(\mathrm{m})$

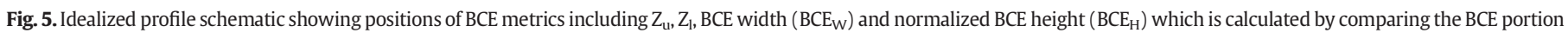
of the profile to a planar profile surface with an average value of $2.3 \mathrm{~m}$ (solid bold line). 
Table 4

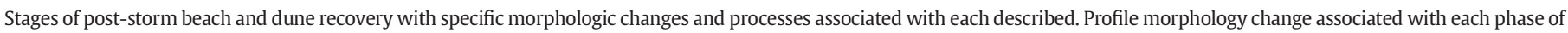
recovery is modified from a Morton et al. (1994) schematic. Corresponding expected BCE change (i.e. $\mathrm{BCE}_{\mathrm{H}}$ and $\mathrm{BCE}_{\mathrm{W}}$ ) provided in far right column.

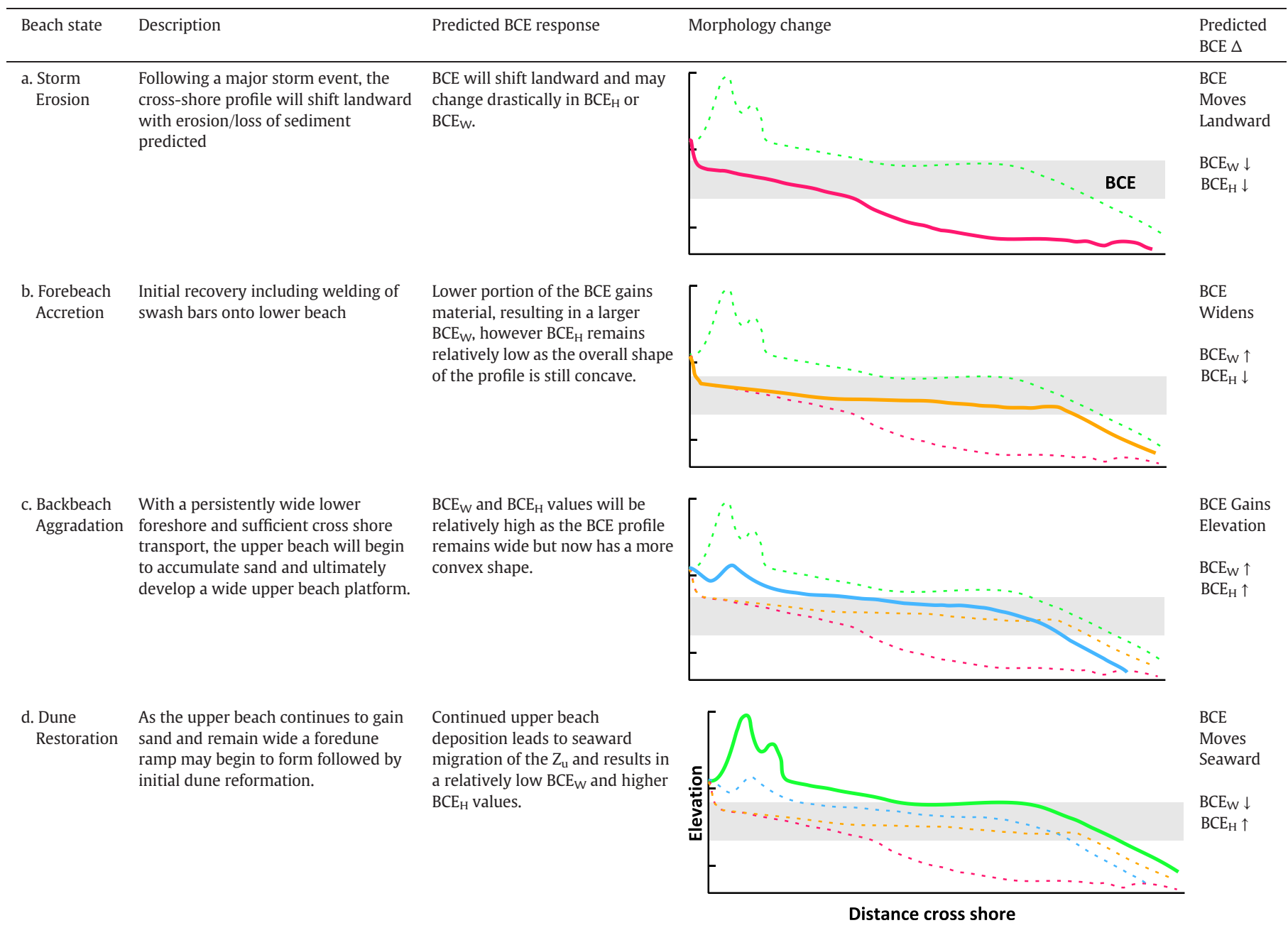

at most profile locations, likely due to ongoing recovery of the system after Sandy, but indications of its initiation (i.e. foredune recovery, dune revegetation, preliminary rebuilding) were evident by the 2014 winter (Fig. 4d).

Building on the initial recovery shown in Fig. $4, \mathrm{BCE}_{\mathrm{H}}$ and $\mathrm{BCE}_{\mathrm{W}}$ values for all available profile locations(i.e. GPS profiles in western and central Fire Island) for four equally spaced post-Sandy survey dates from November 2012 to March 2015 were determined (Fig. 6). By plotting percent deviation from profile specific average values on both axes to fully normalize the data (e.g. Hapke et al., 2016), the general position of individual data points around the $0 \%$ deviation on both axes provides loose categorical boundaries of four identified stages of recovery (Fig. 6 ,

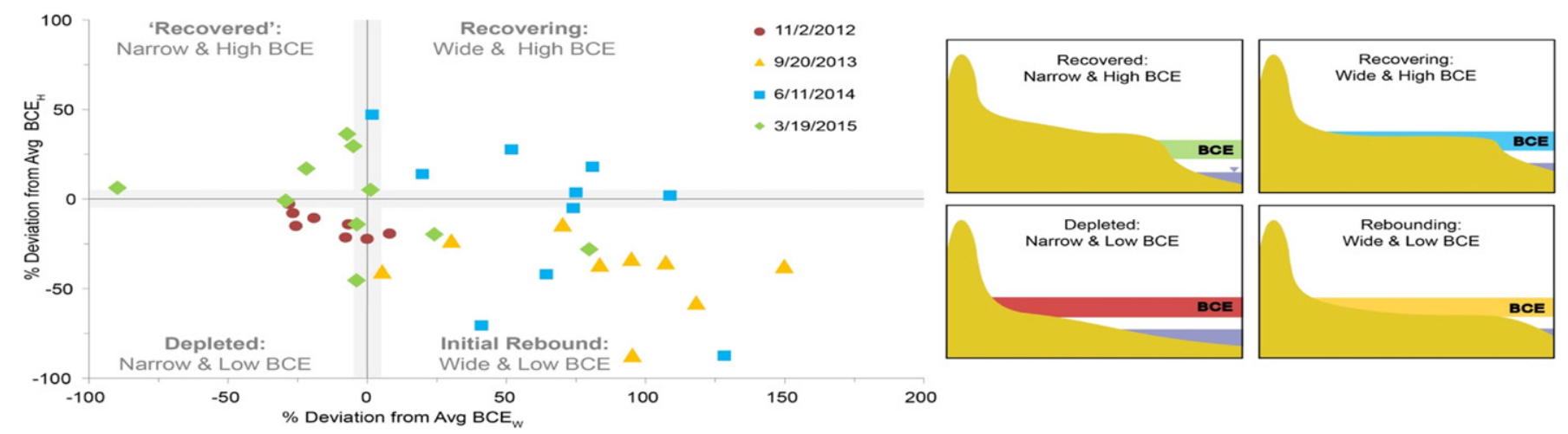

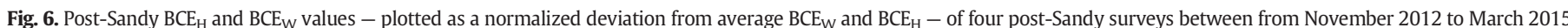

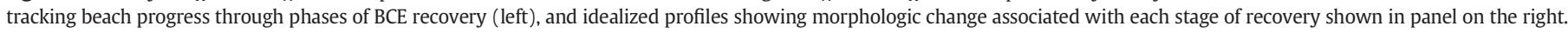

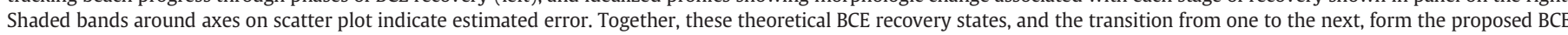
Recovery Regime. 


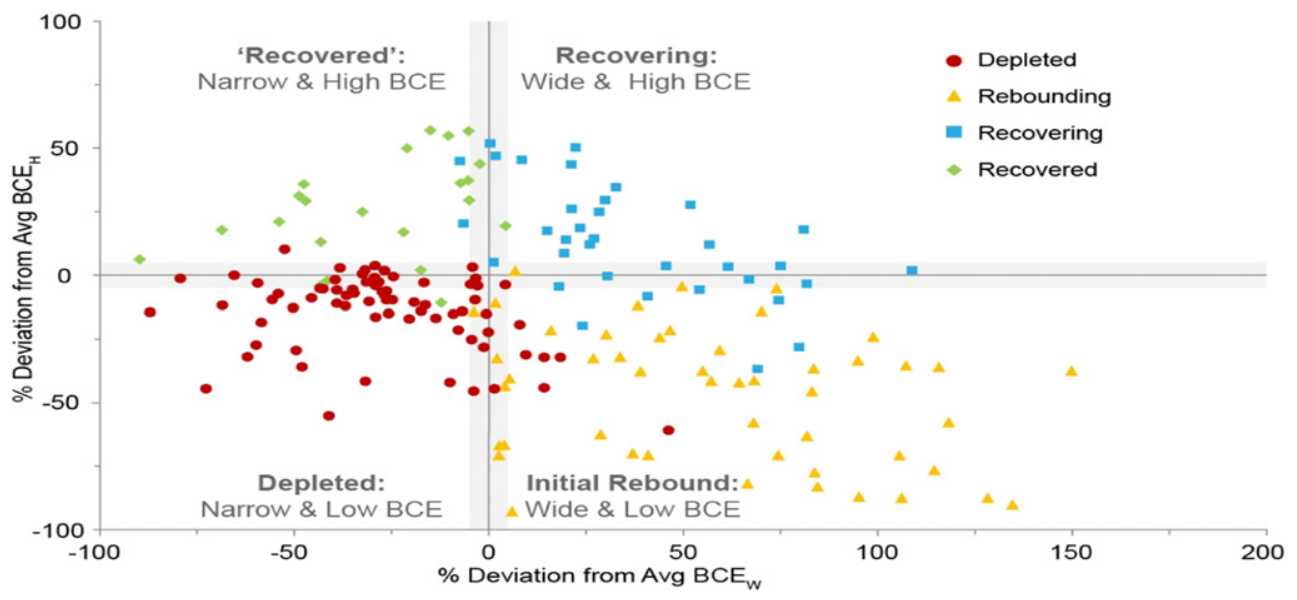

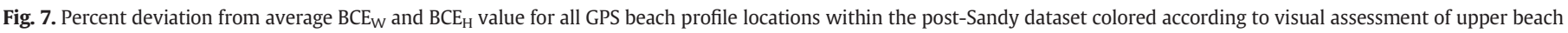
condition. Shaded bands around axes indicated estimated error range.

right panel). The lower left quadrant in these plots (e.g. Figs. 6-8) represents a post-storm 'depleted' condition with low relative values of $\mathrm{BCE}_{\mathrm{W}}$ and $\mathrm{BCE}_{\mathrm{H}}$. Moving counter-clockwise the lower right quadrant reflects the 'initial rebound' phase of recovery as sand moves onshore and $\mathrm{BCE}_{\mathrm{W}}$ increases while $\mathrm{BCE}_{\mathrm{H}}$ remains low. Upper beach accumulation results in higher $\mathrm{BCE}_{\mathrm{H}}$ values $\left(\mathrm{BCE}_{\mathrm{W}}\right.$ remains high also) in the upper right quadrant representing the 'recovering' stage. Finally, as dune regrowth is initiated the $Z_{u}$ moves seaward and the BCE is constricted; $\mathrm{BCE}_{\mathrm{W}}$ declines and high $\mathrm{BCE}_{\mathrm{H}}$ values persist indicating some level of 'recovery' in the top left quadrant.

Three operators visually assessed morphologic change occurring along every profile - specifically, the resulting state of the upper beach and $\mathrm{BCE}$ - within the post-Sandy dataset (Fig. 7). The data tend to fall into four quadrants with distinct values of $\mathrm{BCE}_{\mathrm{W}}$ and $\mathrm{BCE}_{\mathrm{H}}$ based on the inferred recovery state (e.g. Fig. 6). Color coordinated beach state assessments according to numerical value serves to further support the general position of the four quadrants, and shows the progression of recovery among different beach states. Immediately following a storm event, the $\mathrm{BCE}_{\mathrm{W}}$ is narrow and $\mathrm{BCE}_{\mathrm{H}}$ is low as the upper portion of the beach is depleted: eroded, with a steeply sloped and concave shape. Negative $\mathrm{BCE}_{\mathrm{H}}$ values remain in the initial phases of recovery as the elevation of the upper beach remains low due to limited sediment availability; however, the re-introduction of sand from the nearshore to the foreshore and BCE via the welding of nearshore bars results in rapid and substantial widening of $\mathrm{BCE}_{\mathrm{W}}$. As recovery continues, $\mathrm{BCE}_{\mathrm{H}}$ becomes positive (i.e. convex BCE profile) through berm formation, and upper beach elevation gains; a relatively wide $B C E_{W}$ persists into the recovery process as these foreshore deposits accumulate, are transported landward, and ultimately support development of a mature berm. The BCE remains wide with a mature berm and wide upper beach in place until a sufficient amount of sand is deposited near the dune so that the foredune ramp can emerge. Nearing the end of the recovery process, the elevation of the incipient dune begins to exceed $Z_{\mathrm{u}}$ causing the $B C E_{\mathrm{W}}$ to decrease as $\mathrm{Z}_{\mathrm{u}}$ moves seaward with dune reformation. In this recovered stage, $\mathrm{BCE}_{\mathrm{H}}$ maintains a positive elevation and convexity indicative of mature upper beach and dune morphology capable of better withstanding future storm impacts than other stages. Collectively these four beach recovery and response phases, and the proposed progression of the $\mathrm{BCE}$ through each, provides a conceptual recovery framework we refer to as the BCE Recovery Regime that aligns well with previous beach recovery work (Morton et al., 1994; Boothroyd, 1999; Hesp, 2002).

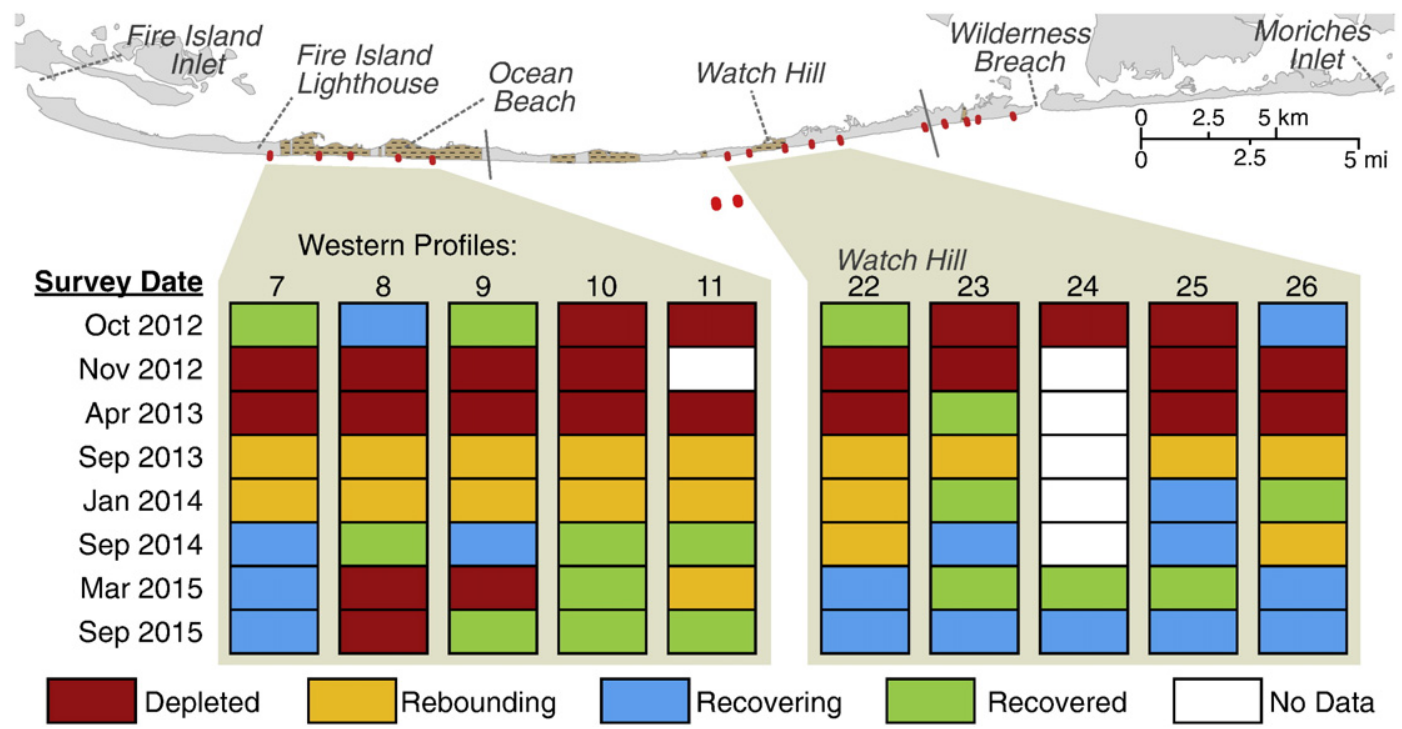

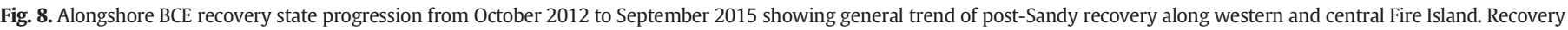

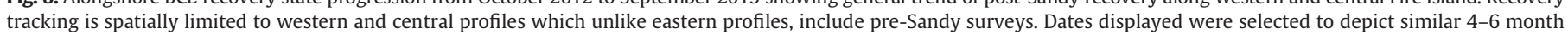
recovery intervals. Locations of communities are marked in tan, and solid gray lines divide the island into 3 distinct geologic regions (i.e. western, central, eastern). 
Reported vertical error values for GPS beach profiles within the postSandy Fire Island database are used to assess uncertainly of $\mathrm{BCE}_{\mathrm{H}}$ and $B C E_{W}$ values and for classifications of BCE recovery state. Henderson et al. (2015, 2017 calculate $\pm 0.063 \mathrm{~m}$ of total vertical uncertainty in reported GPS beach profile surveys. Similarly, to quantify uncertainty values for the LiDAR-derived profiles within the Fire Island dataset, Sallenger et al. (2003) estimate $0.15 \mathrm{~m}$ root-mean-square ( $\mathrm{rms}$ ) vertical error for coastal features extracted from airborne LiDAR data using the feature extraction method outlined in Stockdon et al. (2009). A total error of $0.12-0.15 \mathrm{~m}$ (i.e. a uniformly applied inconsistency) can skew the $\mathrm{BCE}_{\mathrm{H}}$ value by as much as $5.5 \%$. To assess uncertainly in $\mathrm{BCE}_{\mathrm{W}}$, we used an average post-Sandy cross-shore beach slope within the BCE of 0.05 and a vertical uncertainty of $0.063 \mathrm{~m}$ (Henderson et al., 2015), to calculate an estimated $1.3 \mathrm{~m}$ horizontal variability for both $Z_{u}$ and $Z_{1}$. Doubling this value for uncertainty in both the $Z_{u}$ and $Z_{1}$ position, and comparing this potential variability to the average $B C E_{W}$ value for the entire dataset $(24.45 \mathrm{~m})$ results in an estimated $9.4 \%$ of total $\mathrm{BCE}_{\mathrm{W}}$ horizontal uncertainty. Given these values, we conservatively estimate a uniform $10 \%$ error value on beach recovery state classifications (Figs. 6, 7, 9).

Applying the BCE Recovery Regime by exploring stages and their changes through time, provides a way to visually assess alongshore spatial and temporal post-Sandy recovery patterns (Fig. 8). At Fire Island, nearly all western profile locations concurrently transition from 'depleted' to 'rebounding' over the summer of 2013 and to either 'recovering' or 'recovered' by the following 2014 summer. Since then profiles 8-11 have shown variable BCE change, wherein some profiles have briefly reverted to a 'depleted' stage despite showing initial postSandy recovery (i.e., Fig. 8, profiles 8 and 9). In contrast, central profiles (i.e. profiles $23,25,26$ ) - located largely outside communities, with several occurring within the Otis Pike Fire Island High Dune Wilderness Area tract - entered 'recovering' and 'recovered' states earlier (by January 2013). Because classifying the stage of BCE Recovery is limited to recovery of the upper beach region, changes in BCE recovery stages through time (transitions both toward and away from recovery) are expected due to seasonality and stormier periods throughout the year, particularly along the more seaward $Z_{1}$ contour.

\subsection{Applying BCE to additional storms and nourishment}

\subsubsection{9 community nourishments and Nor'Ida}

Although nourishment material was emplaced only on beaches and dunes within communities, accretion was detected at all 15 profile locations along Fire Island in the June 2009 LiDAR survey following project completion. Pre- and post-nourishment profile data show a substantially wider upper beach and the formation of a berm, reflected in BCE metrics: $\mathrm{BCE}_{\mathrm{W}}$ increases by $34 \mathrm{~m}$ on average (Table 5) and increased at all profiles regardless of receiving direct nourishment (Fig. 9a). The island-wide average $\mathrm{BCE}_{\mathrm{H}}$ value does not change, but does increase by $0.2 \mathrm{~m}$ in western Fire Island where profile locations are predominately within communities and therefore directly nourished. Average $\mathrm{BCE}_{\mathrm{H}}$ decreases slightly in the predominately undeveloped central and eastern profile locations of Fire Island (Table 5; i.e. C: $-0.06 \mathrm{~m} \mathrm{E}$ : $-0.05 \mathrm{~m}$ respectively).

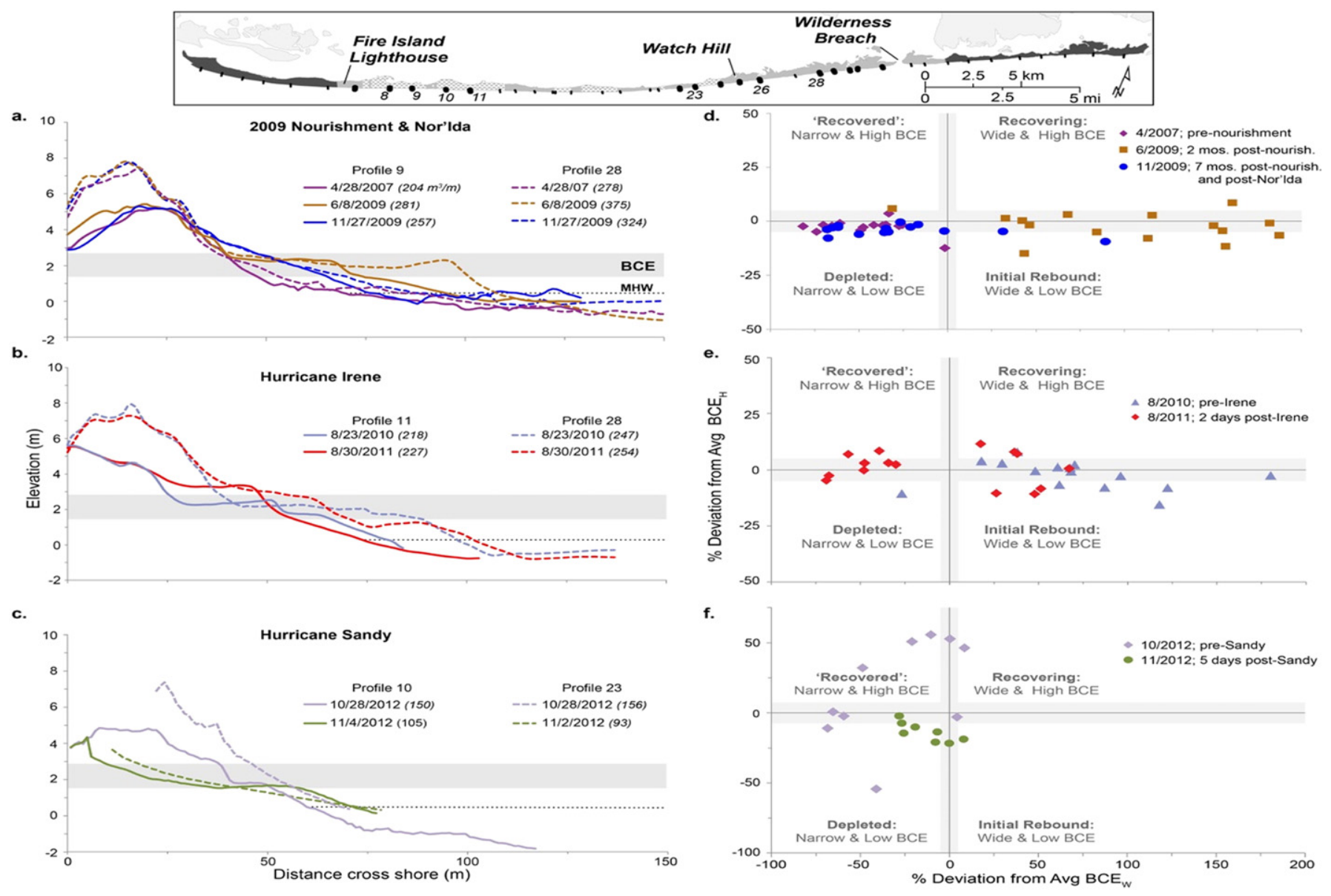

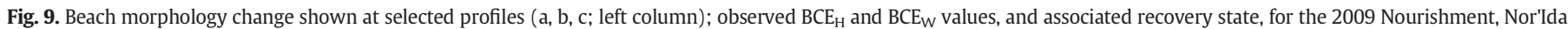

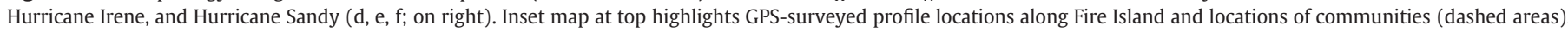

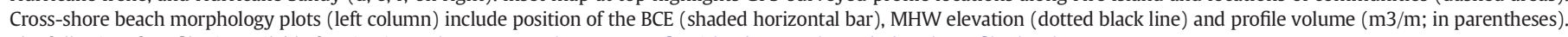
The full suite of profiles is available for viewing at https://coastal.er.usgs.gov/fire-island/research/sandy/beach-profiles.html 
Table 5

Average and standard deviations (in parentheses) of zonal and overall changes in $\mathrm{BCE}_{\mathrm{H}}$ $B C E_{W}$, and $Z_{u}$ and $Z_{1}$ cross-shore position (i.e. negative values reflect landward shift, where positive values reflect seaward shift) at the 15 GPS survey locations.

\begin{tabular}{|c|c|c|c|c|}
\hline & $\mathrm{BCE}_{\mathrm{W}} \Delta(\mathrm{m})$ & $\mathrm{BCE}_{\mathrm{H}} \Delta(\mathrm{m})$ & $\mathrm{Z}_{\mathrm{u}} \Delta(\mathrm{m})$ & $\mathrm{Z}_{1} \Delta(\mathrm{m})$ \\
\hline \multicolumn{5}{|c|}{2009 nourishment (4/2007-6/2009) } \\
\hline West & $30.91(16.50)$ & $0.15(0.13)$ & $1.12(1.83)$ & $32.03(16.35)$ \\
\hline Central & $35.27(17.61)$ & $-0.06(0.18)$ & $-1.04(9.01)$ & $34.23(20.50)$ \\
\hline East & $35.98(9.05)$ & $-0.05(0.14)$ & $-0.65(3.09)$ & $35.33(10.57)$ \\
\hline AVG & $34.06(13.97)$ & $0.01(0.17)$ & $-0.19(5.28)$ & $33.87(15.18)$ \\
\hline \multicolumn{5}{|c|}{ Nor'Ida (6/2009-1/2009) } \\
\hline West & $-9.68(14.29)$ & $-0.19(0.16)$ & $5.28(11.05)$ & $-4.40(8.12)$ \\
\hline Central & $-29.70(18.72)$ & $0.03(0.32)$ & $-0.01(11.39)$ & $-29.71(17.08)$ \\
\hline East & $-33.78(9.05)$ & $0.05(0.12)$ & $-1.02(9.72)$ & $-34.80(2.90)$ \\
\hline AVG & $-24.39(17.34)$ & $-0.04(0.23)$ & $1.41(10.35)$ & $-22.97(17.14)$ \\
\hline \multicolumn{5}{|c|}{ Hurricane Irene (8/2010-8/2011) } \\
\hline West & $-13.98(12.44)$ & $-0.10(0.15)$ & $7.44(10.59)$ & $-6.54(11.97)$ \\
\hline Central & $-16.52(10.65)$ & $0.14(0.14)$ & $8.96(16.30)$ & $-7.56(20.39)$ \\
\hline East & $-21.42(7.39)$ & $0.18(0.22)$ & $10.93(7.47)$ & $-10.50(11.94)$ \\
\hline AVG & $-17.31(10.12)$ & $0.08(0.21)$ & $9.11(11.23)$ & $-8.20(14.27)$ \\
\hline \multicolumn{5}{|c|}{ Hurricane Sandy (10/2012-1/2012) } \\
\hline West & $-3.39(12.25)$ & $-0.54(0.94)$ & $-28.68(12.74)$ & $-25.97(14.67)$ \\
\hline Central & $-3.05(9.23)$ & $-0.23(0.20)$ & $-29.18(4.92)$ & $-32.23(6.24)$ \\
\hline East & $10.47(13.48)$ & $-0.51(1.03)$ & $-34.15(21.74)$ & $-29.04(34.09)$ \\
\hline AVG & $1.34(12.80)$ & $-0.43(0.76)$ & $-30.55(13.16)$ & $-29.08(20.29)$ \\
\hline
\end{tabular}

Profile locations within the communities (primarily located along western Fire Island, Fig. 2b) remained wider post-Nor'Ida; the bulk of $B C E_{W}$ change was caused by movement in $Z_{1}$ location which moved $23 \mathrm{~m}$ landward on average while the $\mathrm{Z}_{\mathrm{u}}$ was largely stationary. Beaches in the central and eastern region, that were not nourished, experienced roughly $32 \mathrm{~m}$ of $\mathrm{BCE}_{\mathrm{W}}$ narrowing on average compared to $10 \mathrm{~m}$ decline in the west. Across all profiles on average, Nor'Ida appears to have limited effect on $\mathrm{BCE}_{\mathrm{H}}$; net change values in the 3 regions hovered around zero, however this is largely a result of highly variable (i.e. positive and negative) values at each profile.

Plotting $\mathrm{BCE}_{\mathrm{W}}$ and $\mathrm{BCE}_{\mathrm{H}}$ values for three surveys starting prior to the 2009 nourishment to 7 months post-completion allowed the tracking of the evolution of beach state (Fig. 9d). Following the April 2009 project completion, BCE values respond to the addition of material to the upper beach by transitioning from 'depleted' quadrant into the wide and elevated 'recovering' phase. Seven months postreplenishment and post-Nor'Ida, the BCE configuration largely shows a pre-nourishment 'depleted' state.

\subsubsection{Hurricane Irene}

Hurricane Irene was an unusual storm for Fire Island as large quantities of sand were deposited onshore, creating a steeper and higher upper beach. Pre- and post-storm profile data indicate sand was moved from lower portion of the beach and berm and deposited in the upper BCE zone, near the dune line (Fig. 9b). The $\mathrm{BCE}_{\mathrm{H}}$ and $\mathrm{BCE}_{\mathrm{W}}$ capture this upper beach accretion: average $\mathrm{BCE}_{\mathrm{W}}$ declines $17 \mathrm{~m}$ as the post-storm upper beach accretion drove $Z_{\mathrm{u}}$ approximately $9 \mathrm{~m}$ offshore (Table 5). $\mathrm{BCE}_{\mathrm{H}}$ remains somewhat constant on average, and increases slightly in the east where pre-storm profiles tended to be particularly low-lying in the $\mathrm{BCE}$. Distinct $\mathrm{BCE}_{\mathrm{W}}$ and $\mathrm{BCE}_{\mathrm{H}}$ values are captured between the pre- and post-storm surveys (Fig. 9e), which when applied to the BCE Recovery Regime, show the profile moving from a wider, low beach, perhaps typified as 'rebounding' or 'recovering' to a more 'recovered' position reflecting the accretional effect of the storm.

\subsubsection{Hurricane Sandy comparison}

Unlike Irene, Hurricane Sandy impacts consisted of upper beach erosion, narrowing, and widely variable dune change. Due to the extreme beach and dune erosion and island flattening, a large portion of the lower beach zone and nearshore region was not within the BCE (Figs. 1b, 9c). Changes in BCE position and morphology were substantial, yet variable alongshore; most notably $\mathrm{BCE}_{\mathrm{H}}$ declined over $40 \mathrm{~cm}$ on average with loss shown at most profile sites across the island (Table 5$)$. BCE $E_{\mathrm{W}}$ remained relatively constant on average $(+1 \mathrm{~m})$ and only showed slight variation among island regions. Instead, dune and upper beach scarping caused both $\mathrm{Z}_{\mathrm{u}}$ and $\mathrm{Z}_{1}$ to similarly shift landward, 6-7 $\mathrm{m}$ on average (Fig. 9f).

Differences in overall storm magnitude and the nature of beach response associated with all events are reflected in $\mathrm{BCE}_{\mathrm{H}}$ and $\mathrm{BCE}_{\mathrm{W}}$ change values. However, when applying the BCE Recovery Regime, erosion during these storms is reflected in nearly all profiles transitioning to a 'depleted' post-storm beach state regardless of pre-storm classifications (Figs. 8, 9).

\section{Discussion}

Collecting spatially comprehensive data that is also temporally sufficient to document the pre-storm condition, track post-storm impacts, and capture recovery, is often very costly (Mason et al., 2000) and therefore challenging to both rapidly deploy and repeat at the required frequency for in-depth analysis (Lee et al., 1998; Houser et al., 2015). Even when some of these datasets might be available, the metrics traditionally used to quantify coastal change may not fully capture the poststorm state of the beach and/or the recovery that follows, such as with Hurricane Sandy at Fire Island (Fig. 1). With the BCE, we sought to develop a metric that could better characterize beach change to a variety of events, over differing spatial and temporal intervals, and flexible enough to be applied to both 2D (i.e. beach profiles) and 3D (i.e. LiDAR) datasets. Our results show the BCE demonstrates a new way to quantify changes in beach morphology that can be applied to an array of spatially and temporally varying datasets, providing both storm impact assessments and the tracking subsequent recovery over a range of intervals (weeks, months, seasons, years). Initially, rigorous assessment of post-Sandy upper beach change resulted in the determination of the BCE and identification of two metrics, $\mathrm{BCE}_{\mathrm{H}}$ and $\mathrm{BCE}_{\mathrm{W}}$, which allowed us to characterize various recovery states within the BCE Recovery Regime.

Examining spatial trends of post-Sandy recovery showed differences in the response of western and central profiles in their recovery trajectories. As noted earlier, western profiles (8-11) located primarily within communities and that have all been artificially restored to some extent since Hurricane Sandy (FIMI, 2014), showed variable recovery, in some cases reverting to a 'depleted' stage after showing initial recovery. By contrast, more centrally located profiles entered recovery stages earlier. Central Fire Island has been noted for historically wider and higher upper beach and dune features (Lentz et al., 2013), relatively stable shoreline (Schwab et al., 2013) and is positioned immediately onshore of submerged glacial outwash deposits that supply most of the island's sediment (Schwab et al., 2013); it is possible the sediment availability works with the robust dune system to accelerate upper beach recovery in this area (Durán and Moore, 2013). These differences in recovery suggest that BCE change may reflect important morphologic distinctions driven by spatially varying processes and geologic framework features alongshore. Additionally, the unprecedented, yet highly variable impact of Hurricane Sandy at Fire Island which resulted in drastically differing pre- and post-storm BCE configurations, further substantiates the incorporation of two components, width and height, into the BCE metric, as assessments of a single $B C E$ value $\left(Z_{u} / Z_{1}\right.$ position, $B C E_{H}$ or $\left.B C E_{W}\right)$ does not accurately characterize BCE state.

Using the BCE methodology to evaluate other storms and the 2009 replenishment shows this metric may be applied to capture upper beach change beyond tracking recovery. Western profiles, most of which were directly replenished or were downdrift and immediately adjacent to the projects, show substantially wider and higher beaches in the survey period following the 2009 replenishment, with seaward shifts of $Z_{\mathrm{u}}$ and $Z_{1}$ reflecting the substantial addition of material to both dunes and beaches (Fig. 9a). By comparison, central and eastern 
profiles, where replenishment was restricted to the locations of only a few profiles, show the wide and low beaches of an 'initial rebound' stage suggesting that seasonal beach building, potentially bolstered by reworked nourishment material, may be in progress but has yet to advance to higher elevations on the beach. Regardless of postreplenishment beach stage, however, we see that nearly all profiles returned to a 'depleted' state - a combination of low $\mathrm{BCE}_{\mathrm{H}}$ and $\mathrm{BCE}_{\mathrm{W}}$ - following Nor'Ida (Fig. 9d) wherein western profiles largely lost $\mathrm{BCE}_{\mathrm{H}}$ and central and eastern profiles lost $\mathrm{BCE}_{\mathrm{W}}$ (Table 5).

The comparison between Hurricanes Irene and Sandy shows how variations in storm intensity and spatial differences in morphologic response are reflected in degrees of $\mathrm{BCE}$ migration and changes in $B C E_{W}$ and $B C E_{H}$ values. The very different impacts from these storms extreme 'beach building' (Irene) and 'beach leveling' (Sandy) events are captured in substantial $\mathrm{BCE}_{\mathrm{H}}$ gains (Irene) driving $\mathrm{Z}_{\mathrm{u}}$ seaward, or losses (Sandy) driving $\mathrm{Z}_{\mathrm{u}}$ and $\mathrm{Z}_{\mathrm{l}}$ landward; coupled with moderate changes to $\mathrm{BCE}_{\mathrm{W}}$ (Table 5), we see the end-member examples of impacts on the upper beach (Fig. 9e,f). However after Sandy, the landward shift of the BCE in many locations, particularly western and central areas, was marked (e.g. Fig. 4; Table 5) and in certain areas of extensive overwash and breaching, $Z_{\mathrm{u}}$ was not measurable (Fig. 8, November 2012 survey at profiles 11 and 24). Nearly four years later, some locations maintain a persistently absent $Z_{\mathrm{u}}$ suggestive of continued vulnerability (e.g. 2 year post-Sandy at profile 24). The subsequent reappearance of $\mathrm{a} \mathrm{Z}_{\mathrm{u}}$ contour in these locations will be the earliest indicator of ensuing post-storm recovery, and can provide important information regarding the timescales and conditions required to re-initiate dune building following large magnitude storms. Furthermore, due to differences in their relative location along the profile, the more elevated $\mathrm{Z}_{\mathrm{u}}$ position is anticipated to be far less variable through time, whereas the more seaward $Z_{1}$ contour is often highly dynamic over seasonal timescales and more likely to capture the morphologic response to smaller events. Therefore coupling the BCE conceptual recovery regime - which we have demonstrated captures relative storm impacts and recovery of the upper beach area - with positional shifts of $Z_{\mathrm{u}}$ and $Z_{1}$ may extend the BCE to track longer term (years to decades) recovery, helping to distinguish where the baseline may have shifted and if absolute (preSandy) recovery can ever be reached.

Analysis of BCE change both in response to post-Sandy storm recovery, as well as historical storm events, supports that the upper beach is sensitive to processes that operate on a variety of timescales from days (storm events) to weekly, monthly, seasonal, annual, and multiyear intervals (recovery). Although our results are spatially limited (10-15 GPS profile locations), they point to the potential for a systematic application of this approach to explore island-wide assessments of beach recovery through spatially continuous datasets (e.g. lidar). Combined with other traditional change metrics, comprehensive spatial and temporal evaluation of upper beach change enhances our understanding of coastal vulnerability, wherein we can gauge where the beach may be less likely to: 1) sufficiently withstand storm events, and 2) promptly recover following an erosional storm event. Ultimately, a more detailed understanding of alongshore upper beach morphodynamics and island vulnerability could be used to develop predictive models and help inform and guide coastal managers and decision makers in the future.

Application of this method elsewhere requires a temporally dense dataset that also captures the historic storm response. Beach profiling, predominately used in this study, is an affordable survey method and many temporally extensive profile datasets are available in which to further test this approach; for example, the UNSW Narrabeen-Collaroy Beach profile dataset (http://narrabeen.wrl.unsw.edu.au/) and various elevation datasets gathered by the USACE CHL - FRF at Duck, NC (http://www.frf.usace.army.mil./frf.shtml). Ideally, both a long record of beach elevation data and high frequency recordings focused around key storm events would be available. In lieu of these more spatially or temporally extensive datasets, pre- and post-storm profile data, even if from a single location, can be used directly assess storm related impacts and post-storm beach state using the BCE approach.

\section{Conclusions}

Traditional methods to quantify shoreline and beach morphology change may, in some cases, provide limited or easily misinterpreted information on the nature of storm impacts and given degree of poststorm beach recovery, such as at Fire Island, New York after Hurricane Sandy (Hapke et al., 2013). We developed the BCE, a contour-based metric, to provide a more comprehensive understanding of the upper beach state following storm events and periods of recovery using a spatially and temporally comprehensive dataset of Fire Island beach profiles. Derived using site specific historic storm response change observations observed from 2005 to 2012, the BCE is located seaward of the dune within the upper beach wave impact zone. Explicit BCE change values for 20 profile survey dates collected in in the three years following Hurricane Sandy are used to track morphologic evolution and are used to develop a conceptual regime that characterizes beach response and recovery. The regime aligns well with previous work on beach response and recovery cycles and consists of four stages of BCE recovery, wherein the upper beach is either: depleted or low and narrow; rebounding, or low and wide; recovering, or high and wide; or recovered, or a high and narrow.

The response to Hurricane Sandy was a substantial landward shift in BCE position, as beaches and dunes were highly eroded during the storm, progressing over time through multiple stages of the natural recovery process. The exact nature and magnitude of these impacts and recovery are variable alongshore and may be linked to spatial differences in anthropogenic influences (i.e. island development and beach modification) and/or geological controls (i.e. underlying stratigraphy and island evolutionary history). We further tested application of the conceptual BCE recovery regime using three historic storms and an extensive beach nourishment project, which allowed us to capture and quantify a variety of event-specific natural and anthropogenic changes in beach. In response to erosional storms (e.g. Nor'Ida and Hurricane Sandy) the BCE typically moves landward and $\mathrm{BCE}_{\mathrm{H}}$ and $\mathrm{BCE}_{\mathrm{W}}$ values decrease, signifying a depleted BCE state. Conversely, accretional events (e.g. 2009 beach nourishment and Irene) generally result in seaward BCE migration, a low BCE $\mathrm{W}_{\mathrm{W}}$ and increased $\mathrm{BCE}_{\mathrm{H}}$ values that correspond with the recovered phase. These assessments, combined with ongoing tracking of post-Sandy BCE recovery stages at multiple locations, can be used to develop predictive models as well as by decision-makers to anticipate future storm response, assess vulnerability, and help guide restoration efforts. Although derived using post-Sandy Fire Island data, with sufficient spatial and temporal data in other locations, we anticipate the BCE methodology introduced in this paper is widely applicable to other barrier island coasts and potentially sandy beach locations worldwide.

\section{Acknowledgements}

We are incredibly thankful for the help and assistance of our partners at the National Park Service: Fire Island National Seashore, especially Jordan Raphael, Michael Bilecki, and Chris Soller. We thank USGS: SPCMSC's B.J. Reynolds for support and data processing, and Joe Long for providing a thorough and careful review. This work was supported by the 2013 Disaster Relief Appropriations Act, Department of Interior Hurricane Sandy Supplemental Project GS2-2B. Any use of trade, firm, or product names is for descriptive purposes only and does not imply endorsement by the U.S. Government.

\section{References}

Aagaard, T., Davidson-Arnott, R., Greenwood, B., Nielsen, J., 2004. Sediment supply from shoreface to dunes: linking sediment transport measurements and long-term morphological evolution. Geomorphology 60:205-224. https://doi.org/10.1016/j. geomorph.2003.08.002. 
Anthony, E.J., Vanhee, S., Ruz, M.H., 2006. Short-term beach-dune sand budgets on the north sea coast of France: sand supply from shoreface to dunes, and the role of wind and fetch. Geomorphology 81:316-329. https://doi.org/10.1016/j.geomorph.2006.04.022.

Boothroyd, J., 1999. Chapter 4: geologic processes. In: Ernst, L.M., Miguel, L.K., Willis, J. (Eds.), Rhode Island's Salt Pond Region: A Special Area Management Plan. Coasta Resource Management Council, Providence, RI :pp. 73-108. http://www.crmc.ri.gov/ regulations/SAMP_SaltPond.pdf.

Bramato, S., Ortega-Sanchez, M., Mans, C., Losada, M.A., 2012. Natural recovery of a mixed sand and gravel beach after a sequence of a short duration storm and moderate sea states. J. Coast. Res. 28:89-101. https://doi.org/10.2112/JCOASTRES-D-10-00019.1.

Castelle, B., Bujan, S., Ferreira, S., Dodet, G., 2017. Foredune morphological changes and beach recovery from the extreme 2013/2014 winter at a high-energy sandy coast. Mar. Geol. 385:41-55. https://doi.org/10.1016/j.margeo.2016.12.006.

Castelle, B., Marieu, V., Bujan, S., Splinter, K.D., Robinet, A., Senechal, N., Ferreira, S., 2015 Impact of the winter 2013-2014 series of severe Western Europe storms on double-barred sandy coast: beach and dune erosion and megacusp embayments. Geomorphology 238:135-148. https://doi.org/10.1016/j.geomorph.2015.03.006.

Davis, R.A., Hayes, M.O., 1984. What is a wave-dominated coast? Mar. Geol. 60:313-329. https://doi.org/10.1016/0025-3227(84)90155-5.

Durán, O., Moore, L.J., 2013. Vegetation controls on the maximum size of coastal dunes Proc. Natl. Acad. Sci. 110:17217-17222. https://doi.org/10.1073/pnas.1307580110.

Farris, A.S., List, J.H., 2007. Shoreline change as a proxy for Subaerial Beach volume change. J. Coast. Res. 23:740-748. https://doi.org/10.2112/05-0442.1.

Fire Island Beach Renourishment Project: Post-construction Report, 2009. Coastal Planning \& Engineering Technical Report.

Fire Island Inlet to Moriches Inlet (FIMI), 2014. Fire island stabilization project: evaluation of a stabilization plan for coastal storm risk management in response to Hurricane Sandy. U.S. Army Corps of Engineers New York District Report. Public Law 113-2 http://www.nan.usace.army.mil/Portals/37/docs/civilworks/projects/ny/coast/fimp/ FIMI_Docs/HSLRR/A-FINAL_FIMI_HSLRR_Report.pdf.

FitzGerald, D.M., Fenster, M.S., Argow, B., Buynevich, I.V., 2008. Coastal impacts due to sea-level rise. Annu. Rev. Earth Planet. Sci. 36:601-647. https://doi.org/10.1146/ annurev.earth.35.031306.140139.

Gutierrez, B.T., Williams, S.J., Thieler, E.R., 2009. Ocean coasts. Coastal Sensitivity to SeaLevel Rise: A Focus on the Mid-Atlantic Region, U. S. Climate Change Science Program, Report 4.1, pp. 43-56.

Hapke, C.J., Brenner, O., Hehre, R., Reynolds, B.J., 2013. Coastal change from Hurricane Sandy and the 2012-13 winter storm season-Fire Island. New York: U.S. Geological Survey Open-File Report 2013-1231 http://pubs.usgs.gov/of/2013/1231/.

Hapke, C.J., Brenner, O.T., Henderson, R.E., 2015. Quantifying the geomorphic resiliency of barrier island beaches. Proc. Coast. Seds. 2015, San Diego, CA https://pubs.er.usgs.gov/ publication/70145272.

Hapke, C.J., Himmelstoss, E.A., Kratzmann, M., List, J.H., Thieler, E.R., 2011. Nationa Assessment of Shoreline Change; Historical Shoreline Change along the New England and Mid-Atlantic Coasts: U.S. Geological Survey Open-File Report 2010-1118. http://pubs.usgs.gov/of/2010/1118/.

Hapke, C.J., Lentz, E.E., Gayes, P.T., McCoy, C.A., Hehre, R.E., Schwab, W.C., Williams, S.J. 2010. A review of sediment budget imbalances along Fire Island, New York: can nearshore geologic framework and patterns of shoreline change explain the deficit? J. Coast. Res. 26:510-522. https://doi.org/10.2112/08-1140.1.

Hapke, C.J., Lentz, E.E., List, J., Warner, J.C., 2012. Impacts of Hurricane Irene at Fire Island, New York: a beach building event. TOS/ASLO/AGU 2012 Ocean Sci. Meeting, Salt Lake City, UT.

Hapke, C.J., Plant, N.G., Henderson, R.E., Schwab, W.C., Nelson, T.R., 2016. Decoupling processes and scales of shoreline morphodynamics. Mar. Geol. 381:42-53. https://doi.org/10.1016/j.margeo.2016.08.008.

Henderson, R.H., Hapke, C.J., Brenner, O.T., Reynolds, B.J., 2015. Hurricane Sandy beach response and recovery at Fire Island, New York: shoreline and beach profile data; Octobe 2012 to October 2014. U.S. Geological Survey Data Series 931. https://doi.org/10.3133/ ds931.

Henderson, R.E., Hapke, C.J., Brenner, O.T., Reynolds, B.J., 2017. Hurricane Sandy beach response and recovery at Fire Island, New York: Shoreline and beach profile data; October 2012 to June 2016. U.S. Geological Survey Data Release https://doi.org/ $10.5066 / \mathrm{f} 7 \mathrm{~g} 15 \mathrm{z} 17$

Hesp, P., 2002. Foredunes and blowouts: initiation, geomorphology and dynamics. Geomorphology 48:245-268. https://doi.org/10.1016/S0169-555X(02)00184-8.

Houser, C., 2009. Synchronization of transport and supply in beach-dune interaction. Prog. Phys. Geogr. 33:733-746. https://doi.org/10.1177/0309133309350120.

Houser, C., 2012. Alongshore variation in the morphology of coastal dunes: implications for storm response. Geomorphology 199:48-61. https://doi.org/10.1016/j. geomorph.2012.10.035.

Houser, C., Hamilton, S., 2009. Sensitivity of post-hurricane beach and dune recovery to event frequency. Earth Surf. Process. Landf. 34:613-628. https://doi.org/10.1002/ esp. 1730 .

Houser, C., Hapke, C., Hamilton, S., 2008. Controls on coastal dune morphology, shoreline erosion and barrier island response to extreme storms. Geomorphology 100: 223-240. https://doi.org/10.1016/j.geomorph.2007.12.007.

Houser, C., Wernette, P., Rentschlar, E., Jones, H., Hammond, B., Trimble, S., 2015. Post-storm beach and dune recovery: implications for barrier island resilience. Geomorphology 234:54-63. https://doi.org/10.1016/j.geomorph.2014.12.044

Kratzmann, M.G., Hapke, C., 2012. Quantifying anthropogenically driven morphologic changes on a barrier island: Fire Island National Seashore, New York. J. Coast. Res. 28:76-88. https://doi.org/10.2112/JCOASTRES-D-10-00012.1.

Lazarus, E.D., 2014. Threshold effects of hazard mitigation in coastal humanenvironmental systems. Earth Surf. Dyn. 2:35-45. https://doi.org/10.5194/esurf-2 35-2014.
Leatherman, S.P., 1985. Geomorphic and stratigraphic analysis of Fire Island, New York. Mar. Geol. 63:173-195. https://doi.org/10.1016/0025-3227(85)90083-0.

Leatherman, S.P., Allen, J.R., 1985. Geomorphic analysis, Fire Island Inlet to Montauk Point, Long Island, New York, Reformulation Study. Coastal \& Environmental Consultants Technical Report, p. 351

Lee, G., Nicholls, R.J., Birkemeier, W.A., 1998. Storm-driven variability of the beach nearshore profile at Duck, North Carolina, USA, 1981-1991. Mar. Geol. 148:163-177. https://doi.org/10.1016/S0025-3227(98)00010-3.

Lentz, E.E., Hapke, C., 2011. Geologic framework influences on the geomorphology of an anthropogenically modified barrier island: assessment of dune/beach changes at Fire Island, New York. Geomorphology 126:82-96. https://doi.org/10.1016/j. geomorph.2010.10.032.

Lentz, E.E., Hapke, C.J., Stockdon, H.F., Hehre, R.E., 2013. Improving understanding of nearterm barrier island evolution through multi-decadal assessment of morphologic change. Mar. Geol. 337:125-139. https://doi.org/10.1016/j.margeo.2013.02.004.

Mason, D.C., Gurney, C., Kennett, M., 2000. Beach topography mapping-a comparison of techniques. J. Coast. Conserv. 6:113-124. http://www.jstor.org/stable/25098328.

Mathew, S., Davidson-Arnott, R.G.D., Ollerhead, J., 2010. Evolution of beach/dune system following overwash during catastrophic storm: Greenwich Dunes, Prince Edward Island 1936-2005. Can. J. Earth Sci. 47:273-290. https://doi.org/10.1139/E09-078.

McCallum, B.E., Wicklein, S.M., Reiser, R.G., Busciolano, Ronald, Morrison, Jonathan, Verdi, R.J., Painter, J.A., Frantz, E.R., Gotvald, A.J., 2013. Monitoring storm tide and flooding from Hurricane Sandy along the Atlantic coast of the United States, October 2012. U.S. Geological Survey Open-File Report 2013-1043 http://pubs.usgs.gov/of/2013/1043/.

McLean, R., Shen, J.S., 2006. From foreshore to foredune: foredune development over the last 30 years at Moruya Beach, New South Wales, Australia. J. Coast. Res. 22:28-36. https://doi.org/10.2112/05A-0003.1.

Morton, R.A., 2002. Factors controlling storm impacts on coastal barriers and beaches a preliminary basis for near real-time forecasting. J. Coast. Res. 18:486-501. http://www.jstor.org/stable/4299096.

Morton, R.A., Gibeaut, J.C., Paine, J.G., 1995. Meso-scale transfer of sand during and after storms : implications for prediction of shoreline movement. Mar. Geol. 126: 161-179. https://doi.org/10.1016/0025-3227(95)00071-6.

Morton, R.A., Paine, J.G., Gibeaut, J.C., 1994. Stages and durations of poststorm beach recovery, southeastern Texas coast. J. Coast. Res. 10 (4):884-908. http://www.jstor.org/stable/ 4298283.

Moser, S.C., Davidson, M.A., Kirshen, P., Mulvaney, P., Murley, J.F., Nuemann, J.E., Petes, L., Reed, D., 2014. Ch. 25: coastal zone development and ecosystems. In: Melillo, J.M., Richmond, T.C., Yohe, G.W. (Eds.), Climate Change Impacts in the United States: The Third National Climate Assessment. U.S. Global Change Research Program : pp. 579-618. http://nca2014.globalchange.gov/report/regions/coasts.

National Oceanic and Atmospheric Administration (NOAA), National data Buoy center, 2010. Buoy \# 44025. http://www.ndbc.noaa.gov/44025.

National Park Service News Release, 2011. Fire Island National Seashore, Fire Island National Seashore reopens after Hurricane Irene: most facilities open by Labor Day weekend. National Park Service News Release, 30 Aug. 2011. https://www.nps.gov/ fiis/learn/news/fire-island-national-seashore-reopens-after-hurricane-irene.htm.

Passeri, D.L., Hagen, S.C., Medeiros, S.C., Bilskie, M.V., Alizad, K., Wang, D., 2015. The dynamic effects of sea level rise on low-gradient coastal landscapes: a review. Earth's Future 3:159-181. https://doi.org/10.1002/2015EF000298.

Phillips, M.S., Harley, M.D., Turner, I.L., Splinter, K.D., Cox, R.J., 2017. Shoreline recovery on wave-dominated sandy coastlines: the role of sandbar morphodynamics and nearshore wave parameters. Mar. Geol. 385:146-159. https://doi.org/10.1016/j. margeo.2017.01.005.

Plant, N.G., Stockdon, H.F., 2012. Probabilistic prediction of barrier-island response to hurricanes. J. Geophys. Res. 117, F03015. https://doi.org/10.1029/2011JF002326.

Priestas, A.M., Fagherazzi, S., 2010. Morphological barrier island changes and recovery of dunes after Hurricane Dennis, St. George Island, Florida. Geomorphology 114: 614-625. https://doi.org/10.1016/j.geomorph.2009.09.022.

Psuty, N.P., Pace, J.P., Allen, J.R., 2005. Coastal foredune displacement and recovery, Barrett Beach-Talisman, Fire Island, New York, USA. Ann. Geomorphol. 141, 153-168.

Psuty, N.P., Silveira, T.M., 2009. Trend in foredune crestline displacement, Fire Island National Seashore, New York, USA, 1976-2005. J. Coast. Res. SI 56, 15-19.

Sallenger Jr., A.H., 2000. Storm impact scale for barrier islands. J. Coast. Res. 16:890-895. http://www.jstor.org/stable/4300099.

Sallenger Jr., A.H., Krabill, W.B., Swift, R.N., Brock, J., List, J., Hansen, M., Holman, R.A., Manizade, S., Sontag, J., Meredith, A., Morgan, K., Ynkel, J.K., Frederick, E.B., Stockdon, H.F., 2003. Evaluation of airborne scanning lidar for coastal change applications. J. Coast. Res. 19:125-133. http://www.jstor.org/stable/4299152.

Saunders, K.E., Davidson-Arnott, R.G.D., 1990. Coastal dune response to natural disturbances. Proc. of Canadian symposium on coastal sand dunes. Natl. Res. Counc. Can., Guelph, Ont., pp. 321-346.

Schlacher, T.A., Dugan, J., Schoeman, D.S., Lastra, M., Jones, A., Scapini, F., McLachlan, A., Defeo, O., 2007. Sandy beaches at the brink. Divers. Distrib. 13:556-560. https://doi.org/10.1111/j.1472-4642.2007.00363.x.

Schwab, W.C., Baldwin, W.E., Hapke, C.J., Lentz, E.E., Gayes, P.T., Denny, J.F., List, J., Warner, J.C., 2013. Geologic evidence for onshore sediment transport from the innercontinental shelf: Fire Island, New York. J. Coast. Res. 29:526-544. https://doi.org/10.2112/ JCOASTRES-D-12-00160.1.

Schwab, W.C., Thieler, E.R., Allen, J.R., Foster, D.S., Swift, B.A., Denny, J.F., 2000. Influence of inner-continental shelf geologic framework on the evolution and behavior of the Barrier-Island system between Fire Island Inlet and Shinnecock Inlet, Long Island, New York. J. Coast. Res. 16:408-422. http://www.jstor.org/stable/4300050.

Scott, T., Masselink, G., O'Hare, T., Saulter, A., Poate, T., Russell, P., Davidson, M., Conley, D., 2016. The extreme 2013/2014 winter storms: beach recovery along the southwest coast of England. Mar. Geol. 382:224-241. https://doi.org/10.1016/j.margeo.2016.10.011. 
Sexton, W.J., Hayes, M.O., 1991. The geologic impact of Hurricane Hugo and post-storm shoreline recovery along the undeveloped coastline of South Carolina, Dewees Island to the Santee Delta. In: Finkl, C.W., Pilkey, O.H. (Eds.), Impacts Of Hurricane Hugo, September 10-22, 1989. J. Coast. Res. 8, pp. 275-290.

Stockdon, H.F., Doran, K.S., Sallenger, A.H., 2009. Extraction of lidar-based dune-crest elevations for use in examining the vulnerability of beaches to inundation during hurricanes. J. Coast. Res. SI 53:59-65. https://doi.org/10.2112/SI53-007.1.

Stockdon, H.F., Sallenger, A.H., Holman, R.A., Howd, P.A., 2007. A simple model for the spatially-variable coastal response to hurricanes. Mar. Geol. 238:1-20. https://doi. org/10.1016/j.margeo.2006.11.004.

Stone, G.W., Baozhu, L., Pepper, D.A., Wang, P., 2004. The importance of extratropical and tropical cyclones on the short-term evolution of barrier islands along the northern Gulf of Mexico, USA. Mar. Geol. 210:63-78. https://doi.org/10.1016/j.margeo.2004.05.021.

Suanez, S., Cancouet, R., Floc'h, F., Blaise, E., Ardhuin, F., Filipot, J.F., Cariolet, J.M., Delacourt, C., 2015. Observations and predictions of wave runup, extreme water levels, and medium-term dune erosion during storm conditions. J. Mar. Sci. Eng. 3:674-698. https://doi.org/10.3390/jmse3030674.

Thieler, E.R., Young, R.S., 1991. Quantitative evaluation of coastal geomorphological changes in South Carolina after Hurricane Hugo. J. Coast. Res. 8, 187-200.

Wang, P., Kirby, J.H., Haber, J.D., Horwitz, M.H., Knorr, P.O., Krock, J.R., 2006. Morphological and Sedimentological Impacts of Hurricane Ivan and Immediate Poststorm Beach Recovery along the Northwestern Florida Barrier-Island Coasts. J. Coast. Res. 226: 1382-1402. https://doi.org/10.2112/05-0440.1.
Warner, J.C., List, J.H., Schwab, W.C., Voulgaris, G., Armstrong, B., Marshall, N., 2014. Innershelf circulation and sediment dynamics on a series of shoreface-connected ridges offshore of Fire Island, NY. Ocean Dyn. 64:1767-1781. https://doi.org/10.1007/ s10236-014-0781-y.

Weinstein, M.P., Baird, R.C., Conover, D.O., Gross, M., Keulartz, J., Loomis, D.K., Naveh, Z. Peterson, S.B., Reed, D.J., Roe, E., Swanson, R.L., Swart, J.A., Teal, J.M., Turner, R.E., van der Windt, H.J., 2007. Managing coastal resources in the 21st century. Front Ecol. Environ. 5:43-48. https://doi.org/10.1890/1540-9295.

Wernette, P., Houser, C., Bishop, M.P., 2016. An automated approach for extracting Barrier Island morphology from digital elevation models. Geomorphology 262:1-7. https://doi.org/10.1016/j.geomorph.2016.02.024.

Weymer, B.A., Houser, C., Giardino, J.R., 2013. Poststorm evolution of beach-dune morphology; Padre Island National Seashore, Texas. J. Coast. Res. 31:634-644. https://doi.org/10.2112/JCOASTRES-D-13-00020.1.

Wilson, K.E. Adams, P.N., Hapke, C.J. Lentz, E.E., Brenner, O., 2015. Application of Bayesian Networks to hindcast barrier island morphodynamics. Coast. Eng. 102: 30-43. https://doi.org/10.1016/j.coastaleng.2015.04.006.

Wright, L.D., Short, A.D., 1984. Morphodynamic variability of surf zones and beaches: synthesis. Mar. Geol. 56:93-118. https://doi.org/10.1016/0025-3227(84)90008-2.

Zeigler, J.M., Hayes, C.R., Tuttle, S.D., 1959. Beach changes during storms on outer Cape Cod, Massachusetts. J. Geol. 67:318-336. http://www.jstor.org/stable/30057084 